
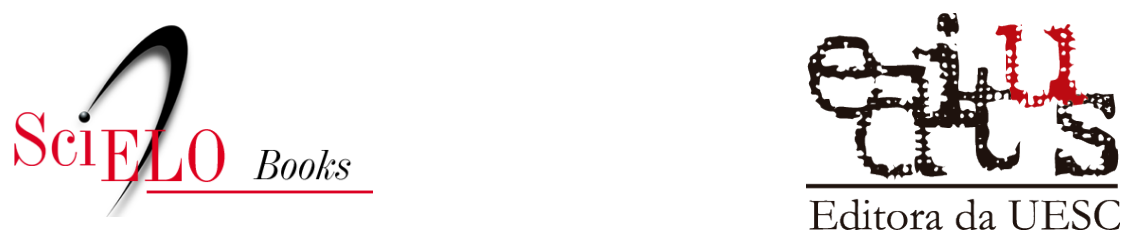

\title{
$4 \mathrm{O}$ eu no outro: reconhecendo-me negro
}

\author{
Ademar Cirne
}

\section{SciELO Books / SciELO Livros / SciELO Libros}

CIRNE, A. O eu no outro: reconhecendo-me negro. In: Racismo religioso em escolas da Bahia: autoafirmação e inclusão de crianças e jovens de terreiro [online]. Ilhéus, BA: Editus, 2020, pp. 63-129. Transfluência series. ISBN: 978-65-86213-16-4. https://doi.org/10.7476/9786586213294.0005.

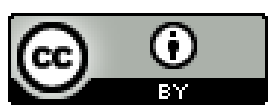

All the contents of this work, except where otherwise noted, is licensed under a Creative Commons Attribution 4.0 International license.

Todo o conteúdo deste trabalho, exceto quando houver ressalva, é publicado sob a licença Creative Commons Atribição 4.0.

Todo el contenido de esta obra, excepto donde se indique lo contrario, está bajo licencia de la licencia Creative Commons Reconocimento 4.0. 


\section{4 \\ O eu no outro: reconhecendo-me negro}

A escrita de um livro sobre educação e relações étnico-raciais não seria possível se eu não tivesse passado por um processo de mudança de pensamento e ações a partir do momento em que entrei em contato com pessoas vinculadas ao movimento negro, que facultaram um conhecimento sobre questões raciais, interferindo muito na minha forma de pensar essas temas.

Durante toda minha vida, desde a infância até a fase adulta, fui formado com uma visão colonialista e eurocêntrica das relações raciais no Brasil. Nascido em uma família pobre, em Salvador, capital da Bahia, residia em um dos espaços mais elitizados da cidade, o bairro do Campo Grande, local privilegiado, no centro da cidade, onde moravam, por volta da década de 1970, as mais tradicionais famílias de Salvador.

Era ali, e em seu entorno, que se localizavam as melhores escolas privadas, os espaços de cultura, as melhores casas e edifícios. Porém, o bairro do Campo Grande, assim 
como outros bairros da cidade do Salvador, tinha outro lado que era periférico, pobre e carente, rodeado de dificuldades sociais. Exatamente neste ambiente, na Ladeira da Fonte, local de casas acanhadas e simples, ocupadas por uma população de classe baixa e muitos pretos e pardos, nasci e passei boa parte da minha vida. A Figura 4, a seguir, ilustra este contraste: os prédios estruturados, como o Teatro Castro Alves e o Colégio do Santíssimo Sacramento (Sacramentinas), e, em segundo plano, a ocupação irregular no vale e o casario ao longo da Ladeira da Fonte.

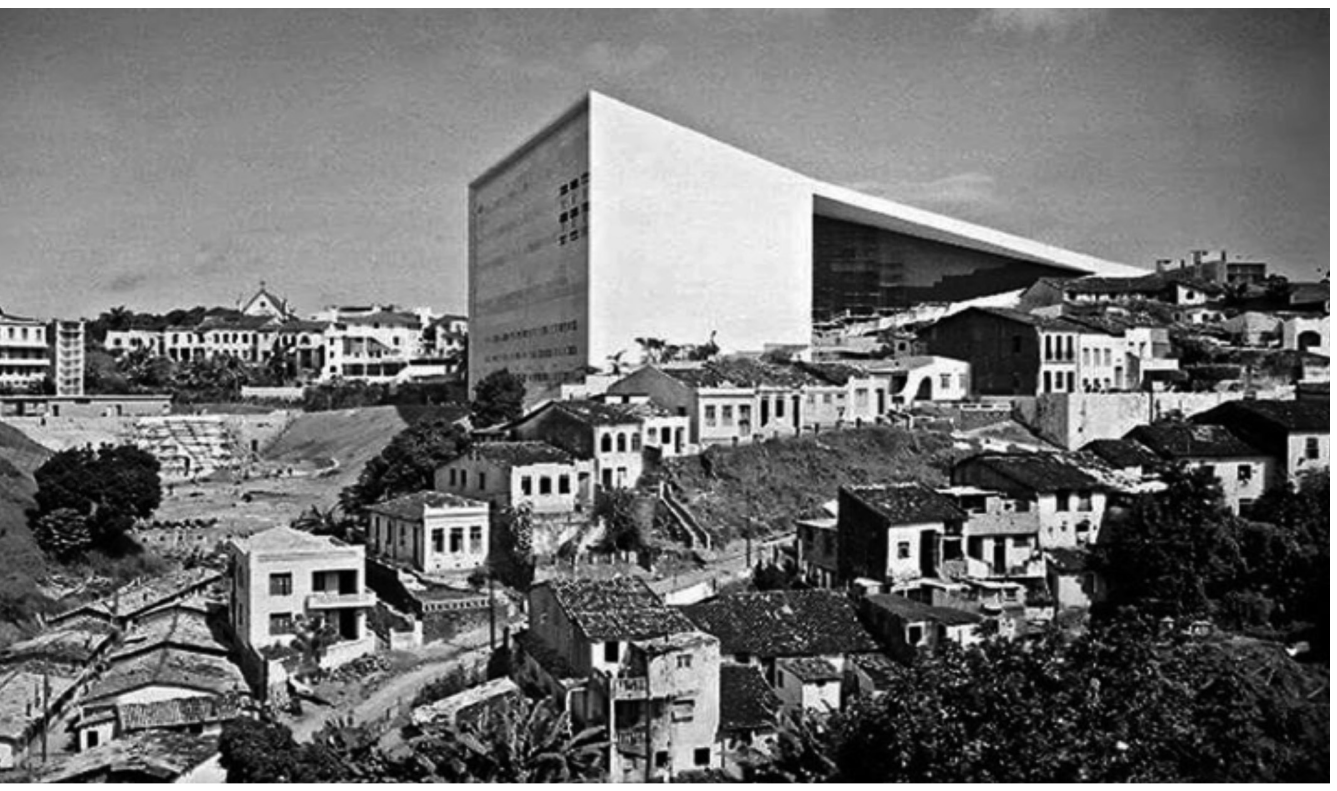

Figura 4

Fonte: Acervo fotográfico do Teatro Castro Alves.

Imagem da Ladeira

da Fonte. 
Ao final da Ladeira existia uma fonte de água limpa, que servia para abastecer as casas dos moradores e também para fornecer água para as senhoras, que ali residiam, ganharem a vida lavando roupa para as moradoras da parte alta do bairro.

Essa pequena descrição social e geográfica do espaço onde vivi a minha infância e juventude permite mostrar que nós, habitantes da parte pobre do bairro, mantínhamos uma relação de dependência e subalternidade com os moradores do lado elitizado, visto que era impossível e mesmo indesejável evitar o contato, pois não tínhamos como chegar em casa sem passar pela parte alta do Campo Grande e, naturalmente, conviver com esses seletos residentes que, por fim, proporcionavam trabalho e renda, apesar das nossas condições precárias.

Qual e como era esta relação? Sempre de subserviência, exploração e subalternidade, principalmente quando hoje percebo que, além da clara diferença social dos grupos, que conviviam teoricamente em perfeita harmonia, havia outra diferença que passava completamente despercebida por quase todos - a diferença racial: nós pardos e pretos e eles brancos. Apesar de tudo que nós passamos, muitas vezes servindo a eles, carregando as compras do mercado, lavando seus carros, cuidando dos seus jardins, não tinha percebido as questões de dominação racial que ali existiam, pois, a ideia de preconceito, discriminação racial, racismo ou coisa parecida ainda não estava presente na minha percepção de mundo.

Naquele momento, década de 1970, prevalecia a ideia de que o Brasil era um país completamente miscigenado 
onde predominava a democracia racial, fundamentada na teoria do cientista social pernambucano Gilberto Freire, escritor do livro Casa Grande e Senzala, que ameniza as diferenças raciais e mostra a harmonia existente entre todos os grupos étnicos brasileiros, como podemos observar abaixo.

Os pretos e pardos no Brasil não foram apenas companheiros dos meninos brancos nas aulas das casas-grandes e até nos colégios; houve também meninos brancos que aprenderam a ler com professores negros. A ler e a escrever e também a contar pelo sistema de tabuada cantada. Artur Orlando refere que seu professor de primeiras letras, em Pernambuco, foi um preto chamado Calisto. Calisto andava de cartola cinzenta, casaca preta e calças brancas. Trajo de gente lorde. De doutores e fidalgos coloniais com medo de hemorroidas ou já sofrendo da maldita doença que desde o século $\mathrm{XVI}$ parece ter perseguido os portugueses ricos ou letrados e seus descendentes no Brasil (FREIRE, 2003, p. 503).

O modo de vida de todos naquele espaço, envolvidos com as pessoas brancas de maior poder aquisitivo, não foi suficiente para eu perceber como a discriminação racial já estava presente durante toda nossa formação (minha e de meus cinco irmãos), pois erramos o reflexo da educação doméstica, seja orientada pelo pai ou pela mãe ou, até mesmo, pela avó.

Minha mãe e meu pai saíam todos os dias antes dos filhos acordarem para o trabalho, e minha educação ficava a cargo de Dona Celina, senhora forte e correta que exercia um papel de liderança em casa e também na comunidade; porém, uma pessoa que teve sua vida toda submetida ao domínio de um companheiro branco, rico e poderoso que, nos moldes patriarcais, determinava como ela deveria se 
comportar. Após o fim do relacionamento, ela veio para a casa de minha família e, quando eu nasci, ela já era a responsável pela nossa educação. Formada no contexto dominador, transferiu este modelo de educação para seus netos. Por exemplo, jamais deveríamos reclamar com ninguém e deveríamos aceitar tudo que fosse determinado pelas pessoas ricas e brancas que convivíamos. Esse modelo de educação doméstica, que não era tão diferente do que nos ensinavam na escola, só fortalecia a ideia de que a vida era maravilhosa e que as diferenças eram apenas a "vontade de Deus que tudo sabe e não deixa faltar nada para todos".

Realmente, em se tratando de coisas materiais, digo, refeições diárias, roupas novas ao final do ano para poder "passar o natal arrumado", livros e cadernos para frequentar a escola, nunca faltavam; faltava apenas entender por que erámos tão isolados pelos outros na hora das brincadeiras, ou por que, quando permitiam que participássemos destas, era sempre fazendo o papel menor, sempre o que perdia ou tomava pancada e não podia reagir, afinal, ali estavam meninos cujos pais ajudavam nossa família.

Assim foi nossa vida (minha e dos cinco irmãos) até a fase adulta, muitas vezes sendo reclamado por nossos pais que evitássemos ficar muito expostos ao sol, pois "corria o risco de ficar mais preto, o que não era bom". Hoje percebo que meus pais, da forma deles, já percebiam o racismo e tentavam de todas as formas esconder a nossa origem, talvez imaginando estarem nos protegendo e, indiretamente, ensinavam que não deveríamos dizer que éramos negros quando alguém perguntasse nossa cor. 
Crescemos com a ideia de que quanto mais clara fosse a cor da nossa pele, menos problemas sociais teríamos, apenas não era dito o porquê dessa necessidade. Eu sentia a discriminação, porém não sabia por que acontecia, pois, apesar de saber que a condição financeira de alguns era melhor que a nossa, isso nunca era usado como argumento para diminuir o outro, pelo contrário, lembro de muitas vezes ser ajudado financeiramente por todos. A questão com certeza era outra, mas eu só iria perceber muitos anos depois.

Logicamente que a ideia de embranquecimento da população brasileira, que sempre se constituiu de maioria negra, já que a base de toda economia colonial e imperial do Brasil se baseou no trabalho escravo por meio do tráfico de negros africanos, contribuiu muito para que eu acreditasse que a ideia de discriminação racial não existia; afinal de contas, eu sempre estava em busca de ser mais próximo do estereótipo branco. Com relação a esta teoria, o que diz Antônio Carlos Lopes Petan (2013, p. 37), na citação a seguir, contribui para esclarecer esse conceito:

Políticas de incentivo a imigração de alemães, italianos e espanhóis foram intensas no decorrer do século XIX e XX. Com o branqueamento da nação pretendia-se atingir uma higienização moral e cultural da sociedade brasileira. Clarear a população para progredir o país passou a ser um projeto de nação defendido no século XIX, mas que avançou pelo século XX. Projeto que envolvia eugenização e a higienização social enquanto políticas públicas.

Esses homens e mulheres foram de fundamental importância para a construção deste país, de acordo com a teoria eugenista, introduzida no Brasil no século XIX e 
permanecida no século XX, a qual pretendia eliminar negros e mestiços do país - alegando serem estes um atraso para o desenvolvimento, fazendo surgir apenas uma sociedade composta de brancos. Muito presente na nossa infância e adolescência, disfarçava todo racismo a que eu era submetido e não entendia.

Com a promulgação da Lei Eusébio de Queiroz, em 1850, que abolia o tráfico negreiro, causando a impressão de que a situação social dos negros melhoraria, a tendência a ter uma diminuição gradativa do número de cativos e mais negros libertos não se concretizou. Vale lembrar que, nesse mesmo ano, o governo do Imperador Pedro ll também sancionou a Lei de Terras no Brasil, estabelecendo o critério censitário para quem quisesse se tornar proprietário de terra no Império, e assim os negros que conseguissem sua liberdade por meio de uma Carta de Alforria ou até mesmo como resultado de lutas, fugas ou revoltas não teriam muita oportunidade de tornarem-se proprietários de terras, pois dificilmente teriam dinheiro para comprá-las e continuariam tendo que trabalhar em áreas dos grandes proprietários rurais.

Não bastasse essa atitude de garantir terras apenas para quem pudesse comprar, impedindo assim o negro ou a negra, até então escravizados, de serem donos de terra, restaria apenas a estas pessoas encontrarem um trabalho digno, que permitisse o sustento da sua família, o que também não aconteceu, visto que foi neste mesmo período que o país abriu suas portas para a entrada em grande quantidade dos imigrantes europeus, brancos, que fortaleceria ainda 
mais a tendência embranquecedora, tão presente naquele momento.

Na adolescência, durante o Ensino Médio, não foi tão diferente da fase infantil, descrita acima, talvez até um pouco pior no que se refere à discriminação racial. Isso porque, quando criança, frequentei escola pública, no próprio bairro, com colegas conhecidos, muitos da mesma rua que eu morava. Porém, ao seguir para o segundo grau, em um momento em que a situação financeira de meu pai e minha mãe tinham melhorado, e as escolas públicas estavam passando por um processo de precariedade enorme, eles fizeram um grande esforço para que eu estudasse em uma escola da rede privada, pois era o filho mais novo e aquele em que depositavam a esperança de, quem sabe, se tornar "doutor", o que não aconteceu.

Não era uma escola particular de alto padrão, porém tinha uma estrutura bem melhor do que as públicas e era frequentada por colegas de um poder aquisitivo maior, na sua maioria de pele branca; esse foi o maior problema a ser enfrentado. Não posso negar que, nos três anos em que frequentei esse espaço de educação, não tive momentos de felicidade e construção de boas relações e amizades; embora, durante toda essa etapa da vida, tenha passado por muitas situações desagradáveis, exclusivamente por conta da minha condição étnico-racial. Situações que, por quase toda minha vida, passaram despercebida, pois eu não tinha a noção de que tantas ações preconceituosas que passei na escola eram práticas claras de racismo.

Os constantes apelidos sempre me vinculando a coisas de cor preta; a exclusão sempre no primeiro momento 
da escolha dos alunos que iriam compor a equipe para um trabalho, mesmo todos sabendo que eu era um bom aluno e que podia contribuir para a realização da atividade; a dificuldade para me aproximar das garotas, que sempre preferiam paquerar os garotos de pele clara - jamais foram percebidos naquele momento. Às vezes, eu até refletia sobre o motivo que me levava a ser excluído das melhores atividades escolares.

Porém, apesar de não entender que tudo que eu passava era por conta da questão racial, inconscientemente tomava atitudes que podiam me fazer um jovem branco, diminuindo assim o desprezo dos colegas. Hoje, eu percebo o quanto era forte a ideologia do branqueamento na minha vida e como estava impregnada na minha mente, a ponto de construir uma sensação de inferioridade que me levava, muitas vezes, a não ter forças para participar de atividades artísticas, científicas, esportivas em igual condição com os outros e, frequentemente, me sentia incapaz para praticá-las, ou mesmo as abandonava. Sem perceber a ideologia do branqueamento, que já estava impregnada em mim, eu acreditava que só me tornando mais branco poderia me inserir na sociedade que vivia. A reflexão exposta pelas professoras Yari e Bento (2012, p. 6) é bem esclarecedora:

\footnotetext{
O branqueamento, todavia, não poderia deixar de ser entendido também como uma pressão cultural exercida pela hegemonia branca, sobretudo após a Abolição da Escravatura, para que o negro negasse a si mesmo, no seu corpo e na sua mente, como uma espécie de condição para se integrar (ser aceito e ter mobilidade social) na nova ordem social.
} 
A teoria do branqueamento ou embranquecimento foi uma das tantas temáticas construídas pela teoria eugenista na segunda metade do século XIX e na primeira do século XX, como já referido. Este pensamento defendia a ideia de que existia um padrão genético superior na raça humana, isto é, os brancos. As teses sustentavam a ideia de que o homem branco europeu tinha o padrão de melhor saúde, da maior beleza e da maior competência civilizacional em comparação às demais raças: amarela, vermelha e negra. No Brasil dos séculos XIX e XX, alguns intelectuais adotaram a teoria do embranquecimento com a intenção de justificar a superioridade da raça branca sobre os negros, principalmente no momento em que a população afrodescendente começava a conseguir, em maior número, a liberdade, o fim do cativeiro.

Para esses pensadores não era possível admitir o desenvolvimento da nação brasileira, povoada por tantos negros, a quem consideravam seres inferiores e responsáveis pelo atraso do Brasil. Era preciso, de acordo com eles, de alguma forma, tornar a sociedade brasileira cada vez mais branca, pois somente assim o Brasil alcançaria a condição de civilização, de nação desenvolvida.

Um dos principais intelectuais brasileiros neste momento foi o médico e antropólogo carioca João Baptista de Lacerda, que em 1911 participou do Congresso Universal das Raças, em Londres, evento que teve como finalidade reunir intelectuais do mundo inteiro para discutir o tema do racismo e da relação das raças com o progresso das civilizações. Este levou ao evento um artigo "Sur lés métis au Bresil" (Sobre os mestiços no Brasil), que defendia o processo da miscigenação como algo brasileiro esse fenômeno 
corresponde à sobreposição dos traços da raça branca sobre as outras, a negra e a indígena. Em um trecho do referido artigo, Lacerda (1911, s/ p) afirma que

\begin{abstract}
A população mista do Brasil deverá ter pois, no intervalo de um século, um aspecto bem diferente do atual. As correntes de imigração européia, aumentando a cada dia mais o elemento branco desta população, acabarão, depois de certo tempo, por sufocar os elementos nos quais poderia persistir ainda alguns traços do negro.
\end{abstract}

Com intenção de justificar ainda mais sua teoria embranquecedora explicada acima, outro fato chamou bastante atenção na participação do intelectual no congresso, a apresentação do famoso quadro do pintor espanhol Modesto Brocos: A Redenção de Cam, apresentado a seguir.

Esse quadro (Figura 5) foi concluído em 1895 e apresenta a imagem de uma família: à esquerda, uma senhora negra olhando para o céu em gesto de agradecimento e uma mulher mestiça segurando uma criança branca; à direita, um homem branco observando a esposa e o filho. A senhora negra, com as mãos para o alto, parece estar agradecendo ao senhor a possibilidade de sua filha, mulata, ter tido uma filha com um homem branco, o que fez dela uma criança bem mais clara que a mãe e que assim, de acordo com a teoria do embranquecimento, na próxima geração dessa família brasileira, os filhos seriam mais brancos e, em algumas gerações futuras, a raça negra, por eles considerada responsável pelo atraso brasileiro, não existiria mais.

A imagem do quadro de Brocos transmite categoricamente a tese que Lacerda (1911) defendia: o 


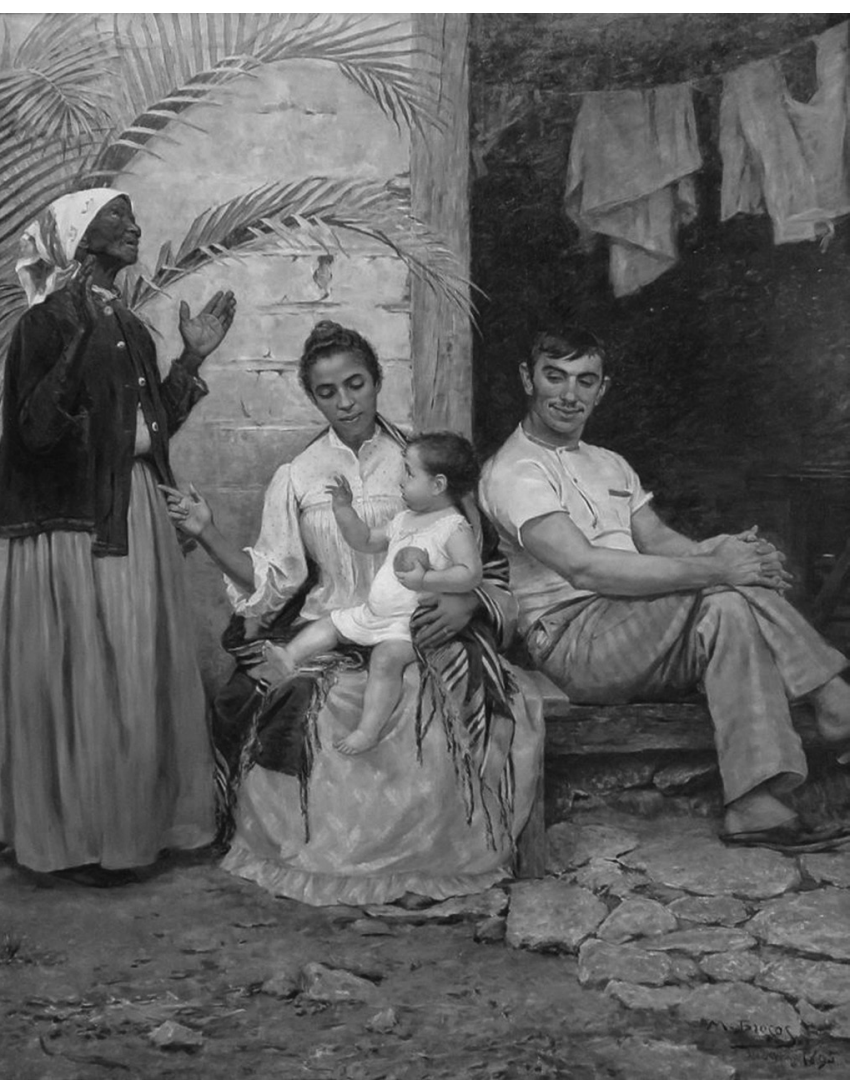

\section{Figura 5}

A Redenção de Cam.

Modesto Brocos,

1895.

Fonte: WIKIMEDIA, s.d 
embranquecimento por meio das gerações. Brocos (1895) propõe a diluição da cor negra na sucessão de descendentes e insere nessa sucessão a "redenção", a "absolvição" de uma "raça amaldiçoada", isto é, a descendência de Cam, filho de Noé, que, no livro do Gênesis, é amaldiçoado pelo pai. A história de Cam, a despeito de seu simbolismo bíblico, foi interpretada à revelia pelo racialismo do século XIX, no qual Brocos estava envolto. O "escurecimento" dos descendentes de Cam teria originado a raça negra africana, que poderia ser redimida por meio da mistura com a raça branca europeia.

Retomando o relato da minha vida, após essa conceituação necessária sobre a teoria do embranquecimento, passo a analisar o período em que eu ingressei na academia, apesar de todas as dificuldades e de muito sofrimento íntimo que passei durante toda minha trajetória, a qual me transformou em uma pessoa com muitos complexos, acreditando que não seria capaz de alcançar o Ensino Superior, que a conclusão do curso de segundo grau e um diploma de técnico era o limite. Porém, resolvi concorrer a uma vaga e fiquei surpreso por ter conseguido ingressar na concorrida Universidade Federal da Bahia (UFBA).

Aprovado no Curso de Licenciatura e Bacharelado em História, tive a impressão de que, a partir daquele momento, em que iria estudar a formação política, econômica, social e cultural do Brasil, poderia entender um pouco de toda aquela inquietação que não permitia que eu fosse um ser inteiro, pleno, confiante e pudesse caminhar olhando para frente, igual à outras pessoas. Minha autoestima estava sempre baixa por me sentir inferior aos outros. 
A trajetória da graduação não trouxe grandes novidades em relação aos estudos raciais, apesar de ter cursado História na Faculdade de Ciências Humanas da UFBA, na década de 1980, quando o Movimento Negro já tinha pelo menos uns dez anos de reorganização e o Movimento Negro Unificado (MNU) já defendia suas ideias por todo o país, apesar do regime de exceção que vivíamos. A universidade, nem mesmo o curso de História e muito menos os conteúdos estudados na Faculdade de Educação, não discutia as questões raciais, pois ainda tinha como referência os estudos fundamentados na perspectiva da democracia racial de Gilberto Freire (2003), explicitada anteriormente.

A base curricular da graduação em História discutia a questão africana durante apenas um semestre, ainda assim como disciplina optativa e com uma ementa que pouco estimulava o seu estudo, longe de alcançar o conteúdo trazido com o surgimento da Lei n. 10.639 (BRASIL, 2003), que determina o estudo da História da África e da Cultura Afro-brasileira nas escolas. Mas eu acredito que, mesmo sem essa determinação legal, um curso de História na UFBA deveria ser mais enfático neste tema. No entanto, a visão predominante era a do eurocentrismo colonizador que subalternizava o pensamento americano, como esclarece a professora Gomes (2008, p. 97), no texto a seguir:

Lamentavelmente, nas faculdades de Educação do país, não será difícil constatar a existência de uma estrutura curricular que sequer inclui o debate sobre as demandas dos movimentos sociais pela educação. As análises presentes nas diferentes disciplinas curriculares dos currículos de licenciatura em pedagogia ainda tendem a privilegiar os conteúdos, desconectados dos sujeitos, a 
política educacional sob o enfoque único do Estado e seus processos de regulação, e as metodologias de ensino sem conexão com os complexos processos por meio dos quais os sujeitos aprendem. O caráter conservador dos currículos acaba por expulsar qualquer discussão que pontue a diversidade cultural Etnicorracial na formação do educador (a). Assim, o estudo das questões indígena, racial e de gênero, as experiências e educação do campo, os estudos que focalizam a juventude, os ciclos de vida e os processos educacionais não escolares deixam de fazer parte da formação inicial de professores (as) ou ocupam um lugar secundário neste processo.

Observo que o estudo da civilização africana nas universidades, mesmo depois da promulgação da Lei (BRASIL, 2003), citada acima, apesar dos esforços de alguns educadores e principalmente do movimento negro, ainda está longe da implementação real dos conteúdos sugeridos pela legislação.

A vida de estudante de graduação não foi muito fácil, pois, quando estava cursando a faculdade, já estava casado e logo nasceu o meu primeiro filho, e foi preciso dividir o tempo de estudo com o trabalho e os cuidados de pai.

Em virtude de estudar em uma universidade federal, onde os horários de aulas eram distribuídos nos três turnos, o trabalho que foi possivel desempenhar foi o de professor em instituições de ensino da rede privada. Como já tinha sido aprovado nas principais disciplinas da licenciatura, não foi difícil a adaptação ao ambiente educacional. E, com muito pouco tempo nesta função, já estava lecionando em instituições conceituadas, tanto no aspecto intelectual quanto no financeiro. Assim, logo passei a conviver com alunos muito ricos e na sua maioria brancos. 
Porém, não só os alunos eram majoritariamente brancos, o corpo docente da instituição quase não tinha professores negros e eu fazia parte de uma exceção. Muitas vezes, na sala dos professores, eu era o único negro, junto com professores brancos, e, mais uma vez, eu não tinha a compreensão de que poderia se tratar de racismo, como já falei anteriormente.

Os conceitos de branquitude construídos na minha infância por minha mãe e minha avó tinham se internalizado e eu não conseguia me perceber, naquele momento, como um homem negro. Eu acreditava que, por não ser negro retinto, naquele ambiente passaria por branco. No entanto, um episódio ocorrido no ano de 1997, em uma das mais conceituadas instituições de ensino da cidade do Salvador, me fez passar por um grande constrangimento.

Este episódio ocorreu quando eu era vice-diretor da instituição de ensino e tinha como uma das minhas atribuições manter o controle disciplinar dos alunos, tendo sido necessário proibir que um deles se ausentasse das dependências da escola antes do término da aula. O aluno, desobedecendo essa orientação, pulou o muro da escola e saiu sem permissão e, como era uma atitude que ia de encontro ao regimento escolar, solicitei a um auxiliar que fosse ver onde ele estava e o reconduzisse à escola. Como era feito normalmente dessa forma, todos os alunos voltavam, se desculpavam e nada mais acontecia. Com esse aluno a situação foi diferente, pois, além de não voltar, ele foi desrespeitoso e ameaçador com o funcionário. Pouco tempo depois o estudante retornou à escola, acompanhado da sua mãe, que desejava saber o que tinha acontecido. 
Quando comecei a relatar o acontecido, a senhora não teve nenhum interesse em saber o que ocorreu, levantou-se da cadeira e deu início a uma série de agressões verbais e, por fim, uma agressão física, que atingiu o meu rosto. Porém, o que mais chamou a minha atenção foi que todas as palavras agressivas proferidas eram relacionadas à questão racial. Embora não me recorde literalmente das palavras, lembro exatamente o que foi dito, referindo-se a ter colocado seu filho para estudar em uma instituição conceituada como aquela, e ele ser proibido de sair por um negro, pobre, despreparado, inadequado para aquela função, em uma escola de pessoas de alta classe social, comunicando que solicitaria a minha demissão da empresa.

Logicamente, esse fato teve consequências. Eu fui à delegacia e registrei uma ocorrência de agressão e ofensa racial, e foi registrada e agendada uma audiência para tratar do assunto. Na presença do delegado, a agressora pediu desculpas e disse que estava arrependida do que fez, que estava vivendo um momento muito difícil.

Naquele momento, final da década de 1990, ainda não era um período em que as denúncias de racismo fossem tão evidenciadas, apesar da Constituição Cidadã de 1988 já ter definido o racismo como crime. Portanto, o fato foi amenizado e configurado como injúria racial, pelo delegado. Os movimentos sociais negros ainda não atuavam rigorosamente como hoje em dia, e por não ter a compreensão das questões étnico-raciais que tenho hoje, não dei prosseguimento à denúncia. Aparentemente, a situação foi resolvida, porém, emocionalmente e psicologicamente, aquele fato me 
marcou por muitos anos, motivando-me a procurar compreender as causas para o que ocorreu.

Não seria difícil dizer o que aconteceu ao final do ano, apesar de tudo ter sido resolvido na delegacia, o que a mãe falou no dia da agressão se concretizou e fui desligado da instituição. O aluno continuou estudando na escola e prevaleceu a lógica do dominador branco e rico sobre o subalterno preto e pobre.

Apesar dos fatos relatados acima, ainda demoraram cerca de dez anos para surgirem os meus primeiros questionamentos a respeito da questão racial e para que fosse possível entender como a condição étnico-racial no Brasil é realmente um fator fundamental no processo de discriminação e racismo. Passei boa parte da minha vida sofrendo discriminação racial e jamais tive a percepção do que acontecia, até esse episódio que ocorreu em 1997, que mencionei acima. Ou seja, eu não tinha nenhuma percepção da minha condição de negro, minha identidade negra não existia e por isso fui humilhado em muitas situações desde a infância, sem compreender os motivos.

Os anos passavam e aquela situação de 1997 era cada vez mais inquietante, às vezes parecia que o tempo se encarregaria de apagar aquelas lembranças que tanto me magoaram, porém, isso não acontecia; sempre que voltava o pensamento para o ocorrido, ou até mesmo passava perto do local onde aconteceu, a emoção era muito grande, e eu lembrava de tudo, com todos os detalhes, e ainda sem entender quase nada da sociedade racista que vivia. Pois, eu acreditava no conceito de democracia racial que relativizava as diferenças raciais e colocava a discriminação como alguma 
coisa inventada pelos negros, já que eu acreditava, também, que no Brasil não existia racismo e que somos uma sociedade miscigenada e diversificada convivendo harmoniosamente, conforme relata Theodoro (2013, p. 3) a seguir:

\footnotetext{
Mas o maior legado da obra de Gilberto Freyre foi a noção de Democracia Racial, largamente difundida pelo discurso oficial governamental a partir da segunda metade dos anos 1940, no período subsequente à Segunda Grande Guerra. O Brasil passa a se apresentar ao mundo - e a se representar - como lugar de convivência harmoniosa e salutar entre pessoas de todas as raças, credos e culturas. Um país sem embates raciais, plenamente miscigenado, verdadeiro exemplo de integração racial.
}

A teoria da democracia racial, em plena década de 1980, ainda era um conceito predominante no curso de história na UFBA e ainda usada como base da nossa formação. Porém, a partir de um encontro inesperado, meu olhar sobre as questões raciais começou a mudar. Esse episódio aconteceu no dia em que recebi a notícia que um ex-aluno, muito querido, tinha sido preso injustamente, acusado de um crime que não havia cometido.

Tratava-se de uma pessoa muito querida, comunicativa e cheia de amigos. Imediatamente, iniciaram uma grande mobilização para entender o que estava acontecendo e, como imaginávamos, nada foi provado; em pouco mais de uma semana, o aluno já estava de volta para casa. No dia do seu retorno, em uma comemoração surpresa, comecei a entender que tantas coisas que passei na vida era devido à minha condição racial e tinha noção dos motivos, digo isso porque foi nesse encontro que tive o prazer e a felicidade de 
ser apresentado ao irmão desse aluno, o professor Marcos Fábio Rezende Correia.

A princípio, percebi que eles eram pessoas diferentes, pois Marcos era uma pessoa fora do padrão que eu estava acostumado a conviver, mesmo morando em Salvador, tendo crescido em um bairro pobre e convivido em espaços de predominância negra. Ele era bem alto, vestido todo de branco, possuía um cabelo diferente, amarrado para o alto, com muitos colares pendurados no pescoço e mais falante do que todas as pessoas presentes. Ele não só falava, mas entrava, saía, gesticulava, atendia e falava no telefone celular, ao mesmo tempo em que conversava com as pessoas.

Aos poucos os amigos foram se ausentando e o ambiente ficando mais vazio e tranquilo e, como a casa de Marcos era próxima à minha, pois a essa altura eu já estava morando no bairro de Pituaçu, próximo do Imbuí e do bairro Boca do Rio, não tive tanta preocupação de sair e, finalmente, me aproximei de Marcos para conversar.

Comecei, então, a entender um pouco do porquê de tanta agitação naquele momento. Na verdade, era ele um dos responsáveis por ter resolvido tão rapidamente a situação do irmão. Aquele encontro, que só foi terminar por volta das 6 horas da manhã, foi o momento da minha vida que comecei a refletir sobre as questões étnico-raciais. Naquele momento, eu tinha conhecido uma das principais lideranças do movimento negro do Brasil, pois, Marcos Fábio Rezende era o Coordenador Nacional do Coletivo de Entidades Negras (CEN), uma organização não governamental, nascida em Salvador no ano de 2003, que é 
O Coletivo de Entidades Negras (CEN) é uma organização que atua pela garantia dos direitos civis das populações negras em seus múltiplos contextos, dimensões e prerrogativas de liberdade individual, de livre manifestação, pensamento e fé, direito de ir e vir e acesso à justiça e demais garantias constitucionais baseadas no princípio internacional da dignidade humana e nas prerrogativas da Conferência de Durban.

Criado em 20 de abril de 2003, o CEN não tem fins lucrativos e congrega entidades e pessoas alinhadas com sua missão, estando presente em 17 estados brasileiros. Suas ações têm, como público-alvo, indivíduos que vivem em situação de vulnerabilidade, excluídos do mercado de trabalho, com baixa escolaridade e sem perspectivas de inserção social, além de povos e comunidades tradicionais, mulheres, LGBTs e juventude negra (CEN, 2018, s.p.).

Além de Coordenador do CEN, Marcos era também Ogã da Casa de Oxumarê, um dos mais antigos e importantes terreiros de Candomblé de Salvador (Figura 6), que, juntamente com o CEN, desenvolvia várias ações voltadas para a defesa das questões étnico-raciais e de combate ao racismo religioso.

Esse encontro inesperado, como dito, começou a provocar uma grande mudança na forma de compreender as relações raciais no Brasil, pois aquele seria um dos muitos encontros que se repetiriam até os dias de hoje.

Naquelas horas de conversa, em que vimos o dia amanhecer, muita coisa foi tratada sempre com foco na história do negro no Brasil, afinal, era o encontro de dois historiadores, pois Marcos era também formado em História pela UFBA. A diferença é que, na década de 1990, quando ele estudou História, já havia outro cenário na universidade, e o estudo de História da África já era uma realidade. Provavelmente, 


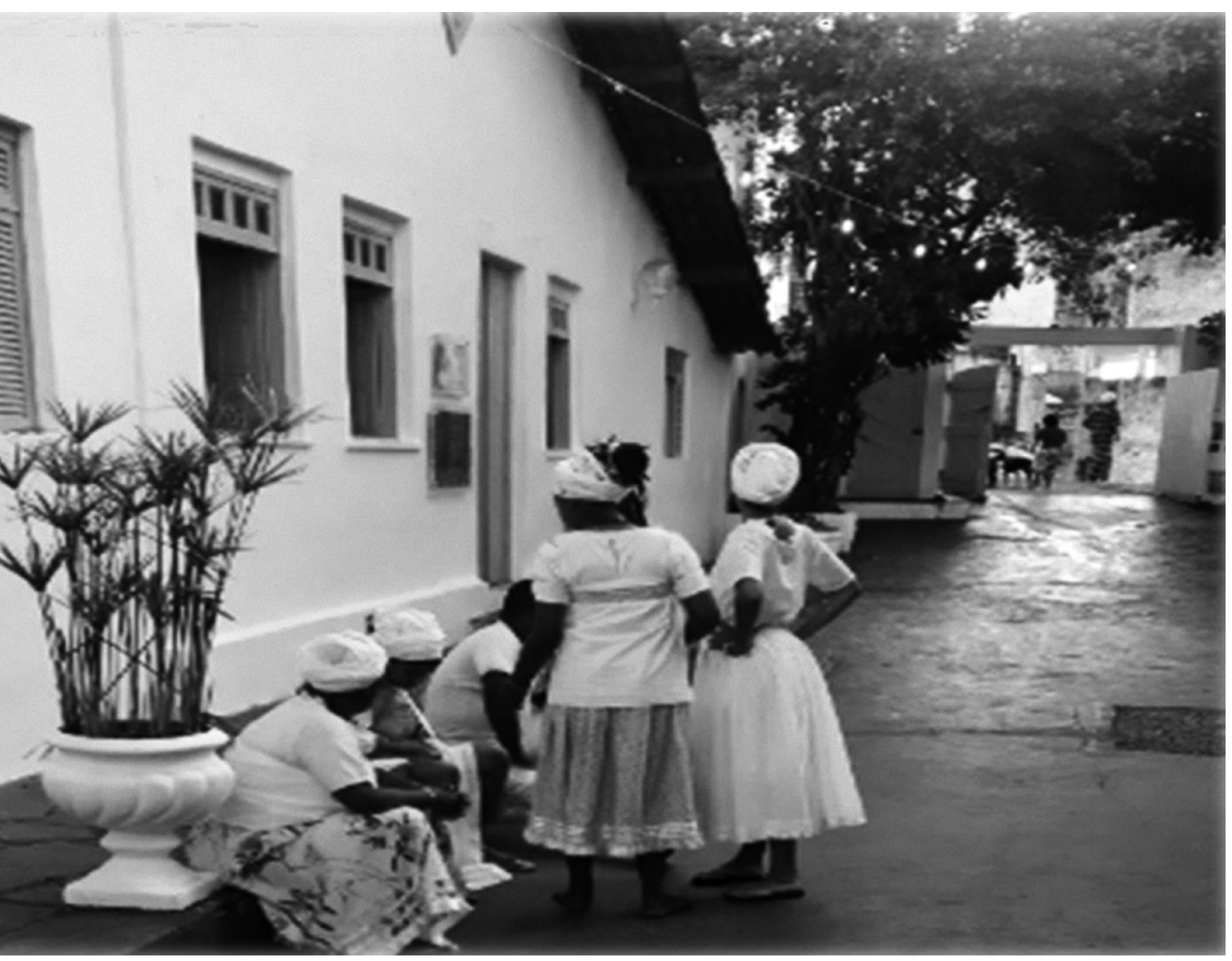

Figura 6

Fonte: dados do pesquisador.

Fachada da Casa de Oxumarê, 2018.

essa formação acadêmica, assim como o seu trabalho desenvolvido como coordenador da escola criativa do Bloco Afro Olodum, no Pelourinho, foi um fator fundamental para que ele tivesse tanto conhecimento e domínio da história da África e sua relação com as questões afro-brasileiras. Nesse sentido, cada conversa que tinha com ele era uma aula sobre essa temática. Estava cada dia mais envolvido e começando a perceber que as informações e as leituras que começava 
a fazer iam descortinando um passado racista e intolerante que vivi sem perceber, por muito tempo.

Uma semana após o primeiro encontro com Rezende, fui convidado a participar de uma reunião no Coletivo de Entidades Negras, que tinha como propósito elaborar um encontro de formação para jovens negros da periferia. Com o tempo, fui percebendo que estes encontros formativos eram parte permanente do CEN, era lá que se discutiam as questões do movimento negro, da sua importância para a história do povo negro brasileiro, e planejavam-se as ações futuras da entidade, além de fortalecer os laços de irmandade dos filiados ao Coletivo.

Com todas essas informações recebidas, fui motivado a aprofundar o estudo das questões teóricas que referendavam essa prática política, o qual envolve a temática étnico-racial. Assim, comecei a estudar os teóricos que dialogam sobre essas questões no Brasil e no mundo. Conheci o pensamento de Malcom X, o de Martin Luther King, aprendi sobre o Pan-africanismo, retomei alguns estudos sobre a história da África, sobre a teoria da democracia racial brasileira e dos intelectuais brasileiros que discutem e criticam esse pensamento, como, por exemplo, Munanga (2010), Lino (2017), Domingos (2007), Matos (2010), Barbosa (2013), Rezende (2013) e Candau (2011). Também revisitei as históricas lutas do movimento negro brasileiro e de como nossos ancestrais se organizaram e lutaram para garantir o direito dos negros e exigir políticas públicas de reparação para a população afro-brasileira, principalmente no que se refere à diminuição do racismo religioso na escola. 
Nesse sentido, passei a refletir sobre qual a contribuição imediata que poderia dar para apoiar aquela juventude negra que agora eu encontrava com frequência; ela despertava em mim uma vontade muito grande de crescimento e participação mais efetiva na sociedade, principalmente nas suas comunidades. Nesse momento da minha vida, além de continuar ministrando aulas na rede privada de ensino, na educação básica, era também diretor de um empreendimento educacional que se dedicava a preparar estudantes para a realização do Exame Nacional do Ensino Médio (ENEM) e de vestibulares. Tal empreendimento consistia no curso pré-vestibular Náutilus, que funcionava no bairro da Pituba e apresentava uma estrutura física que disponibilizava salas de aula em alguns turnos, constituindo uma oportunidade para colaborar com aquela juventude.

Em articulação com a Coordenação do CEN, fiz a proposta de iniciar uma turma preparatória para o ENEM, visando construir condições de acesso da juventude negra ao Ensino Superior.

Essa turma foi composta por jovens negros, moradores de periferias de Salvador, que comprovaram não ter condições de pagar mensalidade nos cursos privados da cidade. A proposta foi muito bem aceita pelos coordenadores e imediatamente começamos os trabalhos. Buscamos parceria com a Secretaria Municipal de Reparação da cidade de Salvador (SEMUR), cujos gestores também gostaram da ideia e juntos iniciamos as atividades. Não foi nada fácil, precisávamos de professores e coordenadores que fossem voluntários e organizamos toda a grade curricular, já que além das disciplinas básicas para a realização do ENEM, seria 
preciso inserir uma disciplina voltada para a discussão das questões afrodescendentes.

Em menos de uma semana de divulgação, foi preciso suspender as matrículas, pois a turma já tinha mais de 200 alunos. Os professores também foram chegando e identificando-se com o projeto; assim, o sucesso foi grande e, no final do ano, vários alunos conseguiram ingressar no Ensino Superior com a ajuda do cursinho.

Ser professor dessa turma, uma experiência que nunca tinha tido, foi de fundamental importância para me aproximar mais daqueles jovens, pobres e simples e, dessa maneira, fui conhecendo histórias dos seus cotidianos que me reportavam à minha infância pobre, de menino negro. As suas dores eram muito parecidas com as que eu tinha passado, que deixaram marcas profundas no meu corpo e na minha alma. Posso dizer que naquele ano aprendi muito mais do que ensinei. O sucesso maior veio no início do ano seguinte, após o resultado do ENEM. Muitos dos nossos meninos e meninas tinham conseguido aprovação e iam começar a realizar seu grande sonho: entrar na universidade e ter o diploma de um curso superior, o que talvez nunca fosse possível sem a iniciativa do CEN e a parceria com o curso Náutilus.

Após essa primeira ação proposta por mim e devido ao resultado superar as expectativas, fui convidado a assumir a Coordenação Estadual de Educação da entidade, cujo trabalho realizei por cerca de dois anos. Nesse período, organizamos novas formações para jovens e novos componentes do Coletivo, assim como para moradores de comunidades quilombolas. 
Com o passar do tempo, fui assumindo outras coordenações estaduais e nacional e a militância no CEN passou a fazer parte do meu cotidiano, por mais que o tempo fosse pequeno, devido às minhas atividades profissionais e familiares. Era, no entanto, impossível ficar distante de tanto aprendizado sobre as questões raciais, assim a convivência com os companheiros e as ações realizadas foram uma verdadeira escola. Ali, comecei a olhar a realidade social e racial do Brasil de uma forma jamais vista antes, constituindo-se em uma "viagem" ao meu passado, a cada discussão, debate, ação prática. Foi realmente um momento transformador do meu ser.

A amizade com o coordenador estadual do Coletivo de Entidades Negras, Marcos Rezende, ainda apresentou muitas surpresas, pois o CEN é uma organização que tem como uma de suas principais preocupações questões relacionadas às comunidades tradicionais de matriz africana, além disso, ele era, também, Ogã do Terreiro llê Axé Oxumarê, como já mencionado. Não demorou muito tempo para ele me fazer o convite para conhecer a instituição, o que de imediato aceitei, pois já tinha essa curiosidade, ou melhor, necessidade, uma vez que a convivência com pessoas do Candomblé era quase que diária, afinal de contas, quase todos os companheiros do CEN eram do Candomblé.

O meu primeiro contato com o Terreiro Oxumarê foi em uma quarta-feira, no início da noite, quando acontece a cerimônia religiosa dedicada ao Pai Xangô - Amalá de Xangố, cujo ritual consiste em oferecer para o orixá uma comida votiva, feita com quiabo cortado, raspa de cebola e azeite de dendê ou de oliva. Nessa cerimônia, os filhos e filhas 
de santo, juntamente com o Babalorixá e os convidados, reúnem-se na porta do quarto do Orixá, cantam, dançam, ouvem a palavra do Pai de Santo, que explica o que significa aquele ritual, pede por todos e deixa uma mensagem de esperança e fé. Após esse primeiro momento as pessoas fazem uma fila e os que já são praticantes da casa, um de cada vez, entram no quarto de Xangô, ajoelham-se, "batem a cabeça no chão" na frente do Santo, fazem seus pedidos e na saída recebem do Sacerdote uma colher do Amalá, que deve ser comido. Ao final, como em toda cerimônia de Candomblé, é servida a mesma comida aos convidados.

Nessa noite, o Amalá se estendeu até quase meia- noite e, como tinha sido convidado e meu anfitrião continuava na casa, também fiquei até a madrugada. Naquele primeiro dia de Candomblé, comecei a perceber o porquê de as pessoas de terreiro dizerem que, depois que passamos do portão de entrada daquele espaço sagrado, o tempo começa a ser contado de forma diferente; tem hora para entrar, porém a saída é por conta dos orixás.

Naquela noite, por exemplo, ter ficado até a madrugada foi muito interessante, pois tive contato mais estreito com a casa e os rituais. Por volta de 1 hora da madrugada, éramos apenas eu, Marcos, o Baba Atinsá7 (Pai Tinho) e o Babalorixá Babá Pecê, conversando sobre a cerimônia que tinha acontecido e sobre vários princípios do Candomblé. Fiquei surpreso de como participei da conversa com aquelas autoridades religiosas com certa desenvoltura, como se já fosse conhecedor da religião, mesmo sendo a primeira vez que tinha contato tão direto com um espaço religioso de matriz africana. Logo, passei a refletir sobre o que vivenciei
6. Comida feita com quiabo, cebola ralada, camarão, azeite de dendê ou doce, oferecida ao Orixá Xangô, servida em gamela normalmente às quartas-feiras.
7. Ogã responsável pelas funções de ebós e liturgia religiosa da casa, guardião dos quartos dos santos e das árvores sagradas. 
naquela noite, tudo que tinha acontecido comigo, desde a curiosidade inicial até a alegria imensa que tinha tomado meu corpo e minha alma.

A participação na conversa após o ritual não foi o que mais chamou minha atenção, mas sim a facilidade com que entendia o que se falava a respeito do Candomblé, pois, apesar de não ter nenhuma vivência prática da religião, possuía conhecimento teórico sobre o tema, uma vez que, nesse período, lecionava na Faculdade UNIBAHIA a disciplina História da Bahia, no curso de graduação em Turismo e Hotelaria, o qual previa em sua ementa o estudo das religiões africanas.

Na semana seguinte, mesmo sem a companhia de Marcos, voltei ao Terreiro para participar do Amalá de Xangô, pois, alguma força espiritual começou a me atrair cada vez mais para o Oxumarê, e a minha ida ao Terreiro foi ficando cada vez mais frequente. Em pouco tempo já estava bem entrosado e sendo tratado como alguém da casa; já era chamado para ajudar em algumas tarefas, principalmente aquelas que dependiam de transporte próprio, considerando que poucas pessoas tinham carro. Aos poucos, fui intercalando o pouco conhecimento teórico que tinha com as vivências práticas que podia presenciar.

O entrosamento com os Filhos de Santo, com os Ogãs, com as Ekedes ${ }^{8}$, as Egbomes ${ }^{9}$ e com o Babalorixá ${ }^{10}$ a cada dia ficava maior e, apesar de tão pouco tempo que eu frequentava o Terreiro, era como se já frequentasse aquele espaço há muito. Na verdade, a minha vivência religiosa por mais de 30 anos tinha sido com a Doutrina Espírita, parte da minha trajetória de vida que ainda não tinha relatado neste memorial. 
Desde muito cedo, por conta de tradição familiar, fui levado a frequentar o Centro Espírita, que funcionava na Federação Espírita do Estado da Bahia (FEEB), situada no Terreiro de Jesus, no centro da cidade do Salvador. Com menos de dez anos já estava participando das aulas de evangelização, aos domingos pela manhã, e com 15 anos comecei a frequentar e realizar atividades com o grupo de jovens, permanecendo lá por toda a adolescência. Ao deixar a juventude espírita, passei a trabalhar em outros Centros, tanto nas reuniões doutrinárias, inclusive como palestrante, quanto nas reuniões mediúnicas, aquelas onde os espíritos se manifestam através dos médiuns. No Candomblé, estes seres desencarnados são os Eguns ou Egum-gum, que em Nagô quer dizer Osso. Mas o seu significado é mais amplo, correspondendo também à "alma de pessoa morta". Esses seres ancestrais não são cultuados no culto de orixás e suas aparições só acontecem em cerimônias específicas, realizadas em espaços religiosos voltados apenas para cultuá-los, o que faz com que os Eguns, nos terreiros de orixás, sejam vistos como energias que não devem ser evocadas, sendo que a conversa sobre eles é bem reservada.

No entanto, a minha familiaridade com essas energias, devido ao atendimento a esses seres, que aprendi na convivência com o espiritismo, fez com que me aproximasse com maior facilidade das pessoas que tinham autoridade religiosa no terreiro. Eles gostavam de conversar comigo sobre o assunto e, assim, a cada dia que passava, a relação com a Casa de Oxumarê foi se estreitando.

No final do primeiro ano que estava frequentando a Casa de Oxumarê, fui convidado a participar de uma das
8. Feminino de Ogã, escolhida pelo orixá e não entra em transe.

9. Cargo do candomblé de quem já cumpriu o período de iniciação (Yaô), na feitura do santo, já tendo feito a obrigação religiosa de sete anos

10. Sacerdote das religiões afrobrasileiras, o mesmo que pai de santo, 0 que faz a consulta aos orixás através do jogo de búzios. 
11. Ritual das Águas de Oxalá que revela o nascimento do Orí

(cabeça) no aiyé (mundo material), rito que normalmente abre as atividades litúrgicas dos calendários das casas de candomblé.

12. Filha de santo do terreiro Axé Opo Afonjá.

13. Cabeça, mente, a inteligência.

14. Fruto sagrado e insubstituível dos rituais de candomblé e umbanda, ele tem diversas utilidades como por exemplo confirmar uma obrigação no candomblé.

15. Toda pessoa que entra para a religião do candomblé poderá ser iniciada ou não, vai depender da sua vontade e principalmente da vontade do orixá. Costuma-se dizer que todos que com frequência estão no terreiro participando das festas públicas são os abians.

16. Uma confraternização espiritual entre pessoas e os Orixás, um ritual de Osè inclui a limpeza do assentamento, 0 preparo e a oferenda dos alimentos de cada Orixá, cânticos, danças e rezas. mais significativas celebrações daquele llê, "As Águas de Oxalá"11, ritual que normalmente abre as atividades religiosas do ano. Na Casa de Oxumarê, essa cerimônia acontece na primeira sexta-feira do mês de janeiro, cujo ritual está descrito abaixo, por Maria das Graças de Santana Rofrigué - Orí Aperê ${ }^{12}$ - Mestre em Ciência da Religião pela Pontifícia Universidade Católica de São Paulo - PUC/SP e pedagoga pela Universidade Católica de Salvador-UCSAL, Omo orixá do Axé Opo Afonjá / Bahia.

\begin{abstract}
Esse ritual anual de purificação, renovação, pode ser considerado um "rito de passagem", o fim e o começo, um novo ciclo, reverencia a presença da água, fonte primordial da vida, que se apresenta em todos os rituais da Religião dos Orixás. O ritual começa na madrugada da sexta-feira com a confecção do baluwê (pequena cabana feita com bambus e de folhagens de coqueiros, pitombas, etc.) o ajubó do Oxalá mais velho será posicionado sobre uma enorme bacia. Outros assentamentos de Oxalá podem ficar ao lado acompanhando o velho Orixá, permanecerão até o $2^{\circ}$ domingo das águas quando então Oxalufan volta para sua casa. Começará então a procissão de ir no rio ou na fonte pegar água fresca, cada um com seu pote, jarro ou quartinha sobre seus Orís ${ }^{13}$, para depois levarem até a cabana de Oxalá e lá a lyalorixá ou Babalorixá estará esperando todos e em ordem hierárquica, receberá as quartinhas com água e lavará o Orí de cada um, colocando um Obi ${ }^{14}$ no Orí cobrindo-o com um ojá. Esse ritual é feito em todos que se encontrarem na casa, abians ${ }^{15}$, iniciados e visitantes, sem exceção, o Orí se renova. Retorna-se ao rio ou fonte mais algumas vezes dando seguimento ao osétb de Oxalá (RODRIGUÉ, 2001, p. 25).
\end{abstract}

A Figura 7, a seguir, mostra um dos momentos desse ritual, quando os participantes saem com suas quartinhas para buscarem a água de Oxalá. 
A minha primeira participação no ritual das Águas de Oxalá foi inesquecível, a energia que circulou no Terreiro naqueles três dias que fiquei por lá era de uma paz imensa e, além disso, eu nunca tinha permanecido no Terreiro por tanto tempo. Tudo era diferente do meu habitual, como deitar em muito silêncio, levantar com o dia clareando, comer comidas quase sem sal e basicamente brancas, enfim, rituais guiados pelo que são considerados como os desejos do Orixá homenageado - Oxalá, e que emanavam uma energia singular e confortante.

Aquele ato foi o que definitivamente determinou a minha escolha pelo Candomblé para seguir como religião. Compreendi que não tinha mais como abandonar tais ensinamentos e realmente queria me tornar um membro daquela casa. O ano novo começou e a minha presença no Terreiro de Oxumarê era cada vez mais frequente. Praticamente toda quarta-feira participava do Amalá de Xangô, visitava a casa sempre que podia para tomar um banho de folhas e estava em todas as festas públicas.

Aos poucos, comecei a participar das funções mais internas da Casa, não chegava como antes para as festas, apenas à noite quando era aberta para o público, mas já participava das celebrações aos Orixás, desde o dia anterior à festa. Assistia ao Orô ${ }^{17}$, ao Padê ${ }^{18}$ de Exu e permanecia no Terreiro até o início do Xirê ${ }^{19}$. Sentia-me feliz, pois, aos poucos, o Babalorixá e os Ogãs mais velhos começavam a atribuir algumas tarefas que eu deveria realizar durante a cerimônia pública, como tomar conta da porta de entrada do barracão, para organizar as pessoas, colocando os homens de um lado e as mulheres do outro; não permitir a entrada de
17. Parte do ritual do candomblé em que, por meio de cânticos e toques mais intensos, os Orixás são chamados a Terra.

18. Cerimônia expiatória do candomblé e de religiões de matriz africana, na qual se oferece a Exu, antes das cerimônias públicas ou privadas, alimentos, bebidas e animais na intenção de que tudo saia bem durante as celebrações

19. Uma palavra Yorubá que significa roda, ou dança utilizada para evocação dos Orixás conforme cada nação. 


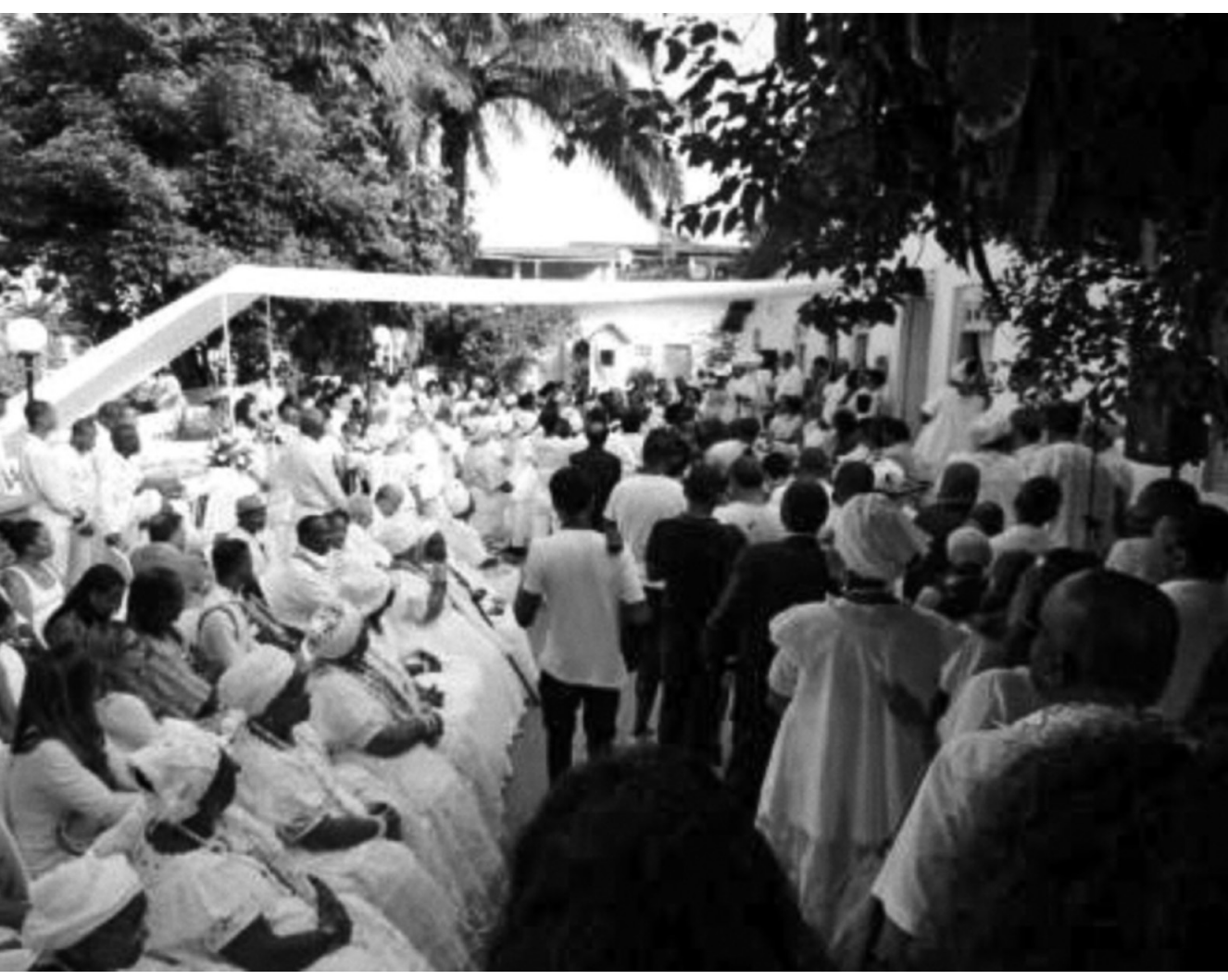

Figura 7

Águas de Oxalá. 
homens no salão vestidos de short ou bermuda; desautorizar o uso de máquina fotográfica para que nenhum visitante fotografasse ou filmasse o Xirê, pois a Casa de Oxumarê não permitia tais registros durante as festas.

Além dessas atividades realizadas no salão, eu já havia sido autorizado pelos mais velhos a receber os visitantes que chegavam para conhecer a festa, cuidar da arrumação da mesa onde seria servida a comida no final, organizar a fila para servir a comida, repor os pratos e lavá-los. Tudo isso parecia muito simples e até humilhante para uma pessoa com formação superior e com uma condição social melhor do que a maioria dos membros da Casa, no entanto, para mim, tudo que fazia e que passei nesses primeiros meses que frequentei o Terreiro era de uma importância muito grande. Foram essas atividades tão simples que desenvolvi que me fizeram entender a importância de uma das frases que se ouvia naquele espaço: depois que passamos daquele portão, todos somos iguais, não importa o título nem posição que tenhamos lá fora.

Eu era, então, um frequentador assíduo de todas as festas do Terreiro, o calendário anual já estava gravado em minha memória, também já tinha feito o meu primeiro jogo de búzios com o Babalorixá, que muito feliz me informou que Oxóssi era o dono do meu Ori - da minha cabeça, o que foi uma imensa alegria para mim também, pois quando militava no movimento espírita, a minha maior afinidade espiritual era com a ancestralidade indígena, ou seja, com os caboclos, que no Candomblé corresponde a uma qualidade de Oxóssi.

Porém, a maior alegria que até agora tive no Candomblé ainda estava por acontecer, e para minha felicidade 
não demorou muito. Ocorreu no terceiro sábado do mês de março do ano de 2008, cerca de um ano após a minha chegada ao Terreiro, na festa do Orixá Yemanjá. Como de costume, cheguei na sexta-feira à noite, dormi no quarto dos Ogãs e sábado, muito cedo, levantei e participei de todas as atividades religiosas preparatórias que antecedem à festa pública. À noite, eu estava pronto para iniciar o cumprimento das minhas funções na festa, já estava na porta do barracão controlando a entrada dos visitantes, quando a Ekede Cida, uma pessoa muito especial para mim no Oxumarê, pois foi ela quem primeiro me acolheu e passou as primeiras informações sobre o Terreiro quando lá cheguei, chamou-me, antes mesmo da festa começar, e disse: "meu irmão, Yemanjá quer falar com você agora". Eu confesso que não entendi do que se tratava, mas como já tinha aprendido que no terreiro não se questiona um chamado dos mais velhos, atendi imediatamente.

Ekede Cida me levou até o quarto das Yaô, onde os santos estavam sendo vestidos, e a Egbome Sandra, que já estava com seu orixá em terra, pegou-me pelas mãos e me deu um forte abraço, separou-se de mim e retornou ao quarto para terminar de se arrumar e ir para o salão. Voltei para a porta do barracão e continuei a desempenhar as minhas funções até aquele momento, que já descrevi anteriormente.

A festa continuou acontecendo. Naquela noite parecia mais linda. Uma energia maior e mais forte do que nas outras, mas como tudo programado, por volta da meia-noite, quando o salão já estava mais tranquilo, os Santos já tinham dançado e passado seu axé. Segui para o barracão de Omolu, 
onde seria servida a comida para os convidados. Como de costume, muita fartura e muita alegria para receber Ajeum ${ }^{20}$, além de muitas risadas e elogios ao sabor da comida.

Nesse momento, quando tudo parecia mais calmo, até os atabaques já tinham silenciado, eu já estava entregando os pratos na cozinha para serem lavados, senti uma mão firme segurando meu pulso, era Yemanjá. Mais uma vez, ela tinha deixado o salão e vindo até o meu encontro. Sem entender muito, deixei que ela me conduzisse até o barracão e, ao entrar, fui recebido com muitas palmas e muita gente desejando que tivesse muito Axé, até que os atabaques voltaram a tocar muito alto.

Então, Yemanjá me entregou ao Ogã André Luís de Xangô, que chamou o Ogã Marquinho de Xangô, Chico de Oxalá e o Babatinsá Luiz Augusto, que me sentaram em uma cadeira e me levantaram, passando pela porta do barracão, pelas portas dos quartos dos santos, pela cumeeira da casa, pelo altar dos atabaques, até me colocarem sentado junto à cadeira do Babalorixá, onde o Babatinsã Luís Augusto dirigiu-se a mim e fez a seguinte pergunta: "Meu irmão, você foi escolhido por Yemanjá para ser o membro desta comunidade, se tornar seu Pai e cuidar das coisas dela, você está sendo chamado a assumir responsabilidades neste terreiro com o cargo de Ogã, você aceita?". Ainda um pouco assustado, respondi que sim, os tambores dobraram tocando e uma fila se formou para me parabenizar. Naquele momento, passei a fazer parte oficialmente da Casa de Oxumarê, foi um dos momentos mais felizes que tive na vida.

Ao acordar, no domingo, fui chamado pela Egbome Lucinha de Omolu, que me segurou pelo braço 
21. Segunda pessoa na hierarquia do terreiro está logo abaixo do Babalorixá, também chamada de Mãe pequena da casa. carinhosamente, levou-me até a Yakekerê21 Sandra Bispo, que até então não sabia que a sua Yemanjá tinha escolhido mais um Ogã para cuidar dela quando estivesse em terra e, ao saber da novidade, a emoção tomou conta da Yakekerê, e Yemanjá imediatamente retornou a terra, para mais uma vez saudar seu Pai. Era muita emoção em muito pouco tempo.

Nesse mesmo domingo aconteceu a cerimônia de entrega do presente de Yemanjá na Praia do Rio Vermelho. Era a segunda parte das reverências ao Orixá que tinha sido iniciada no sábado e, pela primeira vez, eu podia estar bem pertinho do balaio que iria ser levado de barco até o meio do mar, era eu o mais novo escolhido pelo Orixá e era a sua festa, o que me fez sentir muita felicidade. Os irmãos de Santo me parabenizavam, e então senti a emoção de ser parte daquela família ancestral; entendi muito o que era ser do Candomblé, senti-me igual a todos e, finalmente, pude experimentar integralmente o pertencimento à raça negra pela primeira vez na vida.

Ali se encerrava um ciclo na minha trajetória de me descobrir um ser negro, mas muitas coisas ainda aconteceram para que eu pudesse realmente aceitar aquela condição. A relação da Casa de Oxumarê com o Coletivo de Entidades Negras foi ficando cada dia mais estreita, os encontros com os companheiros do Coletivo eram mais frequentes e sempre discutindo a temática relacionada à questão do racismo religioso, ampliando o meu interesse por este estudo. Em uma das primeiras reuniões, tive a oportunidade de conhecer a Yalorixá Mãe Jaciara Ribeiro de Oxum, coordenadora de religiões de matriz africana do CEN, cuja história era muito conhecida, pois ela vinha há muito tempo levantando a 
bandeira do combate ao racismo religioso e havia se tornado uma das principais vozes no Brasil contra essa prática.

Mãe Jaciara deu início a essa luta no ano 2000, logo após ter perdido a sua Mãe biológica, Mãe Gilda de Ogum, vítima de um infarto fulminante, depois de sofrer uma ação perpetrada por membros da Igreja Universal do Reino de Deus (IURD), que invadiram o seu Terreiro jogando pau e pedras e ofendendo verbal e fisicamente as pessoas que ali se encontravam, além de quebrarem objetos sagrados do llê, conforme descreve a seguir a pesquisadora Rego (2008, p. 1):

\begin{abstract}
A saga do Abassá de Ogum, hoje emplacada pela atual lyalorixá Jaciara Ribeiro dos Santos, filha consanguínea de Mãe Gilda, iniciou quando esta resolveu participar das manifestações públicas e populares pela reivindicação do impeachment do então presidente da república brasileira, Fernando Collor de Mello. [...] tudo muito divulgado na imprensa, com ampla cobertura na mídia televisiva, escrita e nas demais formas de comunicação. Entretanto, foi a forma de expressão da Mãe Gilda eleita pela IURD para atacar o povo do Candomblé na sua crença e manifestação prática da sua religiosidade. A revista Veja publicou matéria em 1992, em que aparecia uma foto de Mãe Gilda, trajada com roupas de sacerdotisa, tendo aos seus pés uma oferenda como forma de solicitar aos orixás que atendessem às súplicas daquele momento. A IURD publicou essa fotografia no jornal Folha Universal, em outubro de 1999, associada a uma agressiva e comprometedora reportagem sobre charlatanismo, sob o título: "Macumbeiros charlatões lesam o bolso e a vida dos clientes". A matéria afirmava estar crescendo no País um "mercado de enganação". Nesta reportagem, a foto da Mãe Gilda, aparece com uma tarja preta nos olhos. A publicação dessa foto marca o início de um doloroso, porém definidor processo de luta por justiça.
\end{abstract}


Até os dias de hoje, a Yalorixá Mãe Jaciara de Oxum continua lutando e desenvolvendo atividades de combate ao racismo religioso, além de ter comandado a pasta da Secretaria das Mulheres do Estado da Bahia, também foi coordenadora do Conselho de Desenvolvimento da Comunidade Negra da Bahia (CDCN). Mãe Jaciara consolidou toda sua luta quando, no ano de 2014, inaugurou no Largo do Abaeté, o busto de Mãe Gilda, transformando aquele espaço em local de luta, combate e encontro de membros de vários segmentos religiosos que desejam o fim do racismo religioso. O jornal Correio da Bahia ilustra esse fato na matéria intitulada "Yalorixá Mãe Gilda é homenageada com busto na Lagoa do Abaeté".

Quando os tambores tocaram sob o sol de 10 h de ontem, o olhar decidido e sério de Mãe Gilda, símbolo da luta contra a intolerância religiosa, ressurgiu em um busto em sua homenagem colocado às margens da Lagoa do Abaeté. A escultura, que até o momento da cerimônia estava coberta por um tecido branco, foi celebrada com grãos de milho branco, cânticos e mensagens que valorizavam o que a Yalorixá buscou: paz e respeito. Além da presença de membros de religiões de matriz africana, representantes de outras doutrinas religiosas compareceram ao local reafirmando a intenção de fazer da obra um ponto de referência ecumênica (CORREIO DA BAHIA, 2014).

A matéria enfatizava ainda que os representantes de diversas doutrinas religiosas, presentes na inauguração, reafirmaram a intenção de fazer da obra um ponto de referência ecumênica. A seguir, a Figura 8 mostra a imagem de Mãe Jaciara de Oxum junto ao busto de sua Mãe Gilda. 
Após o falecimento de Mãe Gilda de Ogum, sua filha Jaciara Ribeiro moveu uma ação judicial contra a IURD por danos morais e uso indevido da imagem. Cinco anos após o início do processo judicial, a justiça condenou a IURD, obrigando-a a publicar a sentença proferida pela justiça na capa

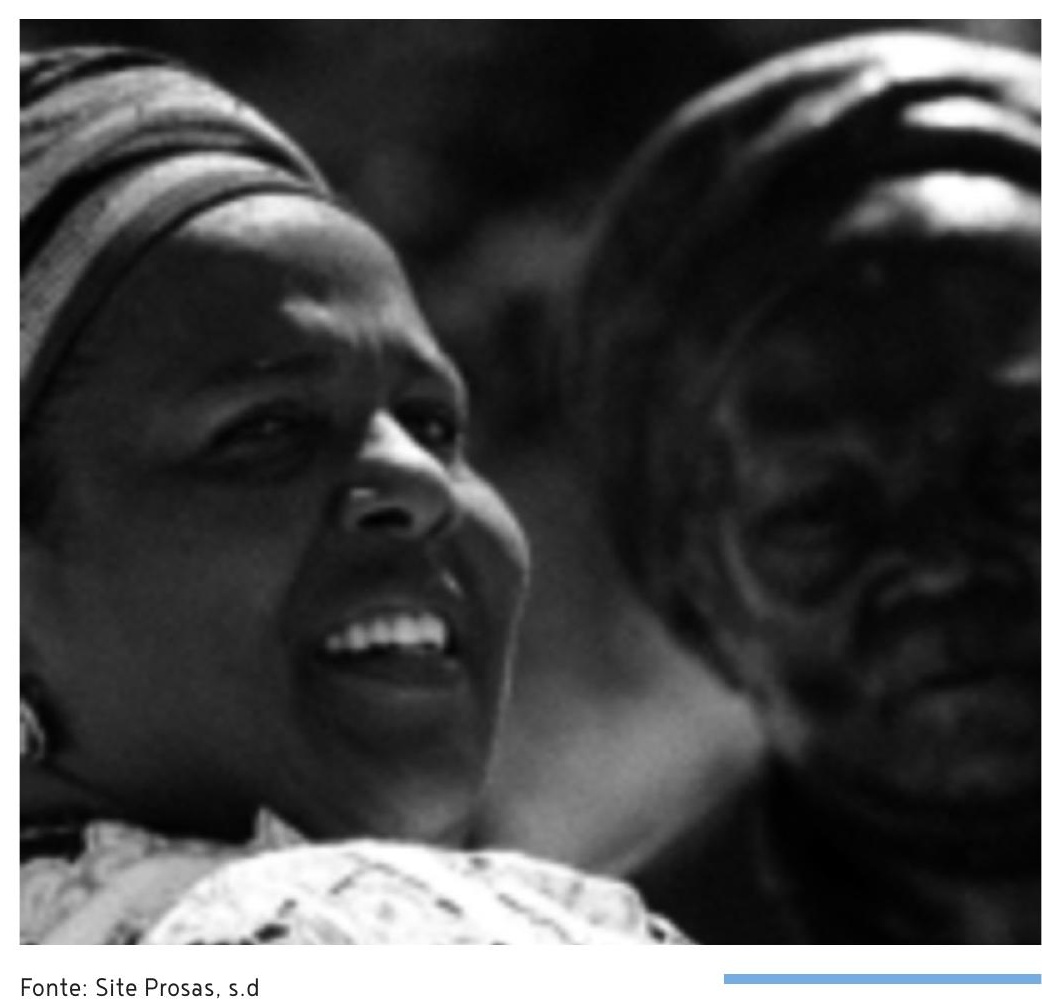

Figura 8

Mãe Jaciara de

Oxum junto ao busto

de sua mãe Gilda 
do mesmo veículo de comunicação que publicou a matéria, pagar R\$1.372.000, correspondentemente a R\$1 por cada exemplar da revista reajustado pelo INPC, desde 1999, além de determinar que o Ministério Público abrisse processo criminal contra a IURD.

A IURD apelou da decisão para o Tribunal da Bahia. Após cinco anos de processo e de muita pressão do povo de Santo, inclusive por meio de manifestações nas ruas da cidade e na porta do Tribunal, a nova decisão ratificava a primeira instância, apenas reduzindo o pagamento da indenização para R\$960.000. Insatisfeita com a decisão da instância estadual, a Igreja Universal recorreu ao STF, que em julgamento ratificou a decisão local por unanimidade, porém, fazendo uma imensa redução no valor indenizatório, que ficou em $\mathrm{R} \$ 145.250,00$. Claro que financeiramente este valor não representaria quase nada para os cofres da igreja nem repararia a perda que sofreu Mãe Jaciara e toda a comunidade religiosa do Terreiro Abassá de Ogum, porém essa não deixou de ser uma importante vitória política na luta contra todo ato de racismo religioso no Brasil.

A partir desse fato, esta temática tomou outra proporção e sua discussão e as ações do movimento negro e das comunidades tradicionais tornaram-se frequentes, fazendo com que a luta se ampliasse por vários segmentos da sociedade, inclusive nos meios acadêmicos. A luta de Mãe Jaciara ganhou expressão em âmbito nacional, tendo a Presidência da República, no ano de 2007, sancionado a lei que estabelecia o dia 21 de janeiro, dia do falecimento de Mãe Gilda de Ogum, Yalorixá do Terreiro Abassá de Ogum, como o dia nacional de combate à intolerância religiosa. 
Minha participação em boa parte dessa luta, principalmente após a filiação no Coletivo de Entidades Negras e convivência frequente com Mãe Jaciara, inclusive no Abassá de Ogum, ampliou o meu interesse pelo tema do racismo religioso. Essa inquietação sempre foi mais forte quando se tratava das crianças e jovens, que eram do terreiro e sempre relatavam as suas dificuldades e as perseguições que sofriam no ambiente escolar, por serem de Candomblé, todas as vezes que se apresentavam com algum elemento ou falavam alguma coisa que fosse relacionada à religiosidade africana. Eram, muitas vezes, isolados e tratados como "filhos do diabo".

Foi conversando com várias crianças e jovens, Filhos de Santo de Mãe Jaciara, que percebi que, enquanto educador, era preciso fazer alguma coisa para diminuir o sofrimento daquelas pessoas. Muita coisa ainda iria acontecer, muitas lutas ainda seriam travadas por mim, pela Casa de Oxumarê e pelo Coletivo de Entidades Negras, até eu entender que um dos caminhos possíveis a seguir para melhorar e contribuir para acabar com essa situação seria produzir materiais didáticos que pudessem ser usados nas escolas pelos alunos e seus professores, motivo que me levou a iniciar a produção de um livro, em forma de cartilha, com esta temática durante o curso de mestrado.

Durante os anos de 2008 a 2014, tive a oportunidade de, juntamente com o CEN e outros setores do movimento negro, participar de várias outras lutas, além das relatadas acima, em defesa de Terreiros de Candomblé contra ações de racismo religioso sofridas por essas instituições. 
A primeira esteve relacionada a um dos mais duros golpes já sofridos por uma casa de Candomblé na Bahia, na atualidade. Trata-se de uma ação promovida pela Superintendência de Controle e Ordenamento do Uso do Solo da Cidade do Salvador (SUCOM), órgão da Prefeitura Municipal de Salvador, que, em uma manhã de quarta-feira, chegou com seus prepostos e aparato policial militar, com uma suposta ordem de despejo e reintegração de posse da área, onde há mais de 29 anos estava localizado o Terreiro llê Axé Oyá Onipó Neto, da sacerdotisa Mãe Rosa de Oyá. Mãe Rosa, antes de esboçar qualquer reação, ou seja, antes de ter direito de fazer alguma explicação, mesmo tendo em suas mãos documentos que comprovavam a propriedade do terreno, viu sua casa quase toda derrubada, em menos de 30 minutos, sem ter como impedir.

Imediatamente, a notícia se tornou pública e várias autoridades religiosas da Bahia, líderes de movimentos negros, entre eles o CEN, assumiram a defesa por meio da divulgação do fato nos órgãos de imprensa, que, no mesmo instante produziram reportagens no local. As ações em defesa promovidas pelo Povo de Santo e por movimentos sociais provocaram grande repercussão, fazendo com que a demolição fosse suspensa de imediato; a discussão agora seria na esfera judicial e por meio da pressão diária sobre o prefeito de Salvador. Passeatas, audiência, vigílias, intervenção de órgãos de direitos humanos do Brasil e do mundo fizeram o prefeito voltar atrás na sua decisão, determinando a reconstrução de toda a área destruída, além de exonerar a gestora da SUCOM, responsável pelo ato, bem como procedeu ao pagamento de indenização para a Mãe de Santo. As fotos (Figuras 9, 10 e 11) e os relatos da época mostram, 
com mais clareza, os trágicos fatos sofridos por toda aquela comunidade religiosa.

Conforme podemos observar nas figuras 9, 10 e 11 e na citação a seguir, a destruição do terreiro llê Axé Onipó Neto foi quase que total, porém, mesmo vindo a público pedir desculpas, a responsável pela ordem da demolição foi exonerada do cargo pelo prefeito de Salvador.

O terreiro Oyá Onipó Neto, localizado há mais de 29 anos na Avenida Jorge Amado, em Salvador, foi parcialmente demolido em 27 de fevereiro, o que provocou polêmica e uma série de manifestações contra a intolerância religiosa. A responsável por autorizar a demolição, Kátia Carmelo, foi exonerada do cargo de chefia da Superintendência de Controle do Uso do Solo do Município (Sucom) e o prédio está sendo reconstruído. De acordo com a prefeitura, a demolição foi ordenada por um suposto problema na escritura. Em nota, Kátia Carmelo disse que percebeu ter havido excesso na ação dos prepostos da Sucom, pediu desculpas alguns dias após a derrubada do prédio, o prefeito de Salvador, João Henrique Carneiro, pediu desculpas pelo ocorrido, em público, e anunciou que o templo seria reconstruído. Segundo a mãe-de-santo Rosalice Santos do Amor Divino, de 50 anos, uma construtora, cujo nome é mantido em sigilo, assumiu a obra (ARAÚJO, 2008, s.p.).

O segundo episódio que presenciei e participei ativamente, relativo ao racismo religioso, aconteceu no ano de 2012 após a ação judicial que determinou a devolução do terreno localizado no bairro de Brotas, em Salvador, onde há mais de 50 anos estava localizado o Terreiro llê Axé Airá Izô, da Sacerdotisa Mãe Angélica de Ogum.

De acordo com informações de Mãe Angélica, o Terreiro estava localizado em um terreno cedido à Yalorixá pelo 


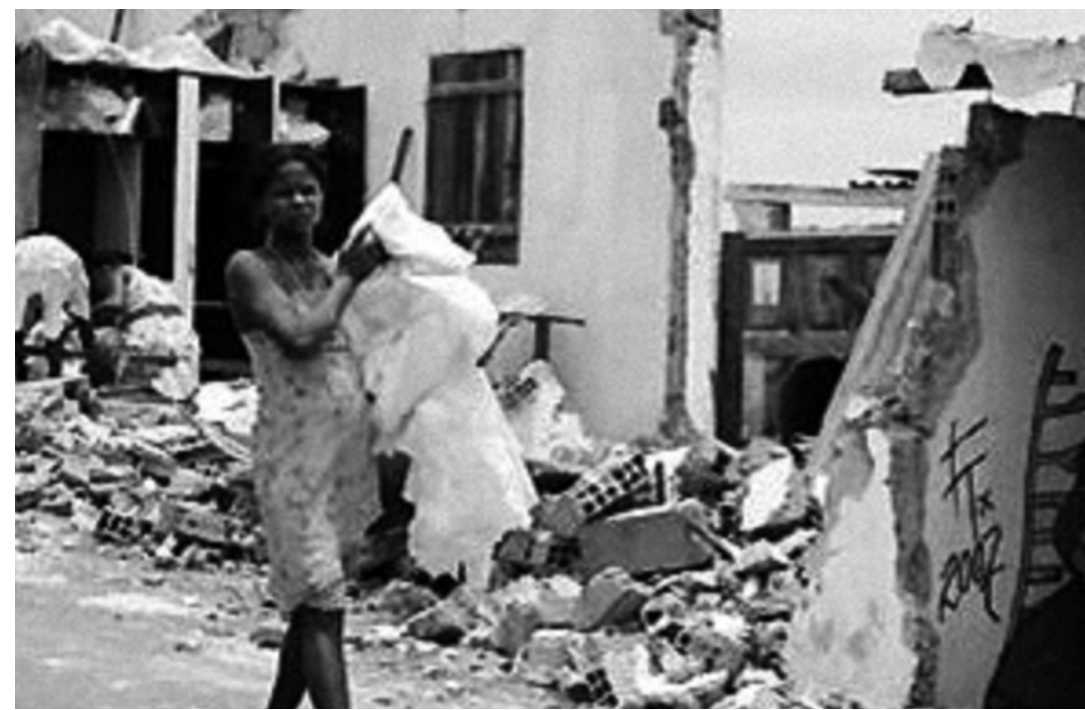

Fonte: Revista Fórum, 2008

Figura 11

Imagem do Terreiro llê Axé Onipó Neto. demolido. 
proprietário, há cerca de 50 anos, logo após ter alcançado a cura da sua filha, que, conforme os médicos, não sobreviveria por muito tempo. A criança, que tinha na época cerca de 4 anos de idade, foi recolhida no Terreiro por um tempo e saiu sem nenhum problema de saúde. Em gratidão a dona Angélica, Mãe de Santo que acolheu e cuidou da sua filha, o dono da terra presenteou a Yalorixá com toda a área.

Muitos anos depois, a criança que havia sido cuidada e curada por dona Angélica, que era sua afilhada, entrou na justiça reivindicando a posse do terreno. Na época da doação, a área em questão era periférica, distante do centro urbano e de pouco valor financeiro; porém, no momento em que foi ajuizada a ação, o terreno onde o Terreiro estava localizado pertencia a um dos locais bem valorizados de Salvador. Por vários anos a disputa pelo terreno foi travada na justiça; porém, nesse momento a Mãe Angélica não esteve sozinha nessa disputa, pois uma mobilização dos movimentos sociais que lutam contra o racismo religioso esteve presente por meio de manifestações, passeatas, acompanhamento das audiências e pressão sobre o governo estadual que, finalmente, decidiu desapropriar o terreno e garantir a permanência do Terreiro naquele espaço.

A atitude do governador foi resultado de uma ação pública mobilizada por autoridades religiosas da Bahia e do Coletivo de Entidades Negras durante uma solenidade de lançamento da Sétima Mostra de Direitos Humanos, com a participação da ministra Maria do Rosário e do governador Jaques Wagner e outras autoridades. Na oportunidade, a ministra declarou: "Direitos Humanos se constrói assim, nas ruas" (AMORIM, 2012, s.p.). Segue trecho da reportagem 
intitulada "O Axé quebra protocolo para proteger tradições afrodescendentes":

[...] Governador Jacques Wagner se sensibiliza com a situação
do llê Axé Ayrá Izô ameaçado de demolição e anuncia desapro-
priação do terreno onde funciona terreiro para proteção das tra-
dições afrodescendentes. Na noite da última Segunda-Feira, 10
de dezembro, o Pelourinho voltou a ser palco de momentos de
grande relevância para a história e a cultura afrodescendente. Era
para ser apenas a abertura oficial da 7 a Mostra de Direitos Huma-
nos, mas representantes do llê Axé Ayrá Izô e outras autoridades
religiosas, vestindo o branco de Oxalá, quebraram o protocolo e
celebraram a terceira noite da Festa para lansã no palco montado
para a solenidade. Em meio às atividades pelo Dia Internacio-
nal dos Direitos Humanos, a manifestação estava chamando a
atenção das autoridades, personalidades e demais presentes para
o risco iminente de demolição do Terreiro com mais de 50 anos
de atividades, por força de uma ação de reintegração de posse.
(AMORIM, 2012, s/p).

O resultado vitorioso desse movimento foi de significativa relevância, não só por reparar uma injustiça contra - Terreiro em questão, a sua Yalorixá e aos demais participantes da Casa, mas também por demonstrar a importância da organização social na conquista de direitos em geral e, particularmente, no avanço em relação à igualdade racial e respeito às diferentes religiões; no caso, o Candomblé. A Figura 12, a seguir, ilustra a participação do Povo de Santo e dos movimentos sociais na defesa dos seus direitos.

Na imagem abaixo (Figura 12), os adeptos do Candomblé vestem a cor branca, cor de Oxalá, o orixá que simboliza a paz. Hoje, o Terreiro llê Axé Airá Izô segue suas funções em paz, com seu espaço assegurado, desenvolvendo 
suas atividades religiosas e os trabalhos sociais para a comunidade.

A terceira atividade que desenvolvi em conjunto com o CEN foi bem mais prazerosa que as duas anteriores, pois não foi luta para reconstrução de Terreiro nem disputa na justiça para garantir a posse de terreno. Essa ação foi resultado de um edital do governo do estado da Bahia, vencido pelo

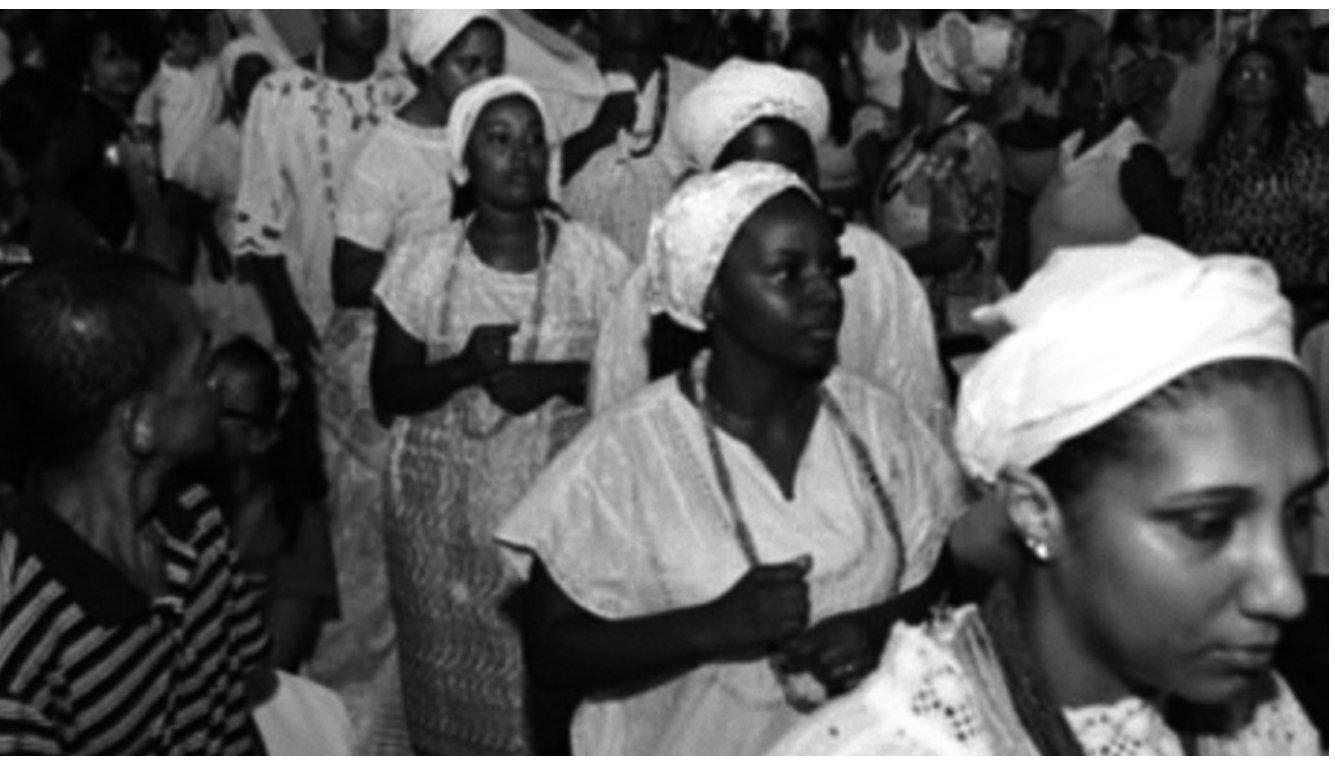

Figura 12

Imagem do ato do

Povo de Santo na

abertura oficial da $7^{a}$

Mostra de Direitos

Humanos. 
Coletivo de Entidades Negras em parceria com a TV Pelourinho, que consistiu na produção de um livro que retrata a história de cerca de 300 mulheres de Axé de Salvador, de outros municípios da Região Metropolitana de Salvador e da região do Recôncavo baiano.

Após as primeiras reuniões para discutir a elaboração do livro, decidimos que usaríamos a metodologia de pesquisa direta com as mulheres selecionadas, e para isso contratamos os pesquisadores, fotógrafos, maquiadores, motoristas e os tabuladores dos dados da pesquisa e produtores do texto final. Para minha alegria, eu fui escolhido como coordenador geral da pesquisa, o que permitiu que acompanhasse todos os grupos e fizesse contato com a maioria das senhoras entrevistadas. Nossa primeira preocupação foi com o critério para a escolha das Mulheres de Axé que seriam selecionadas para participar do projeto editorial e, depois de muitas reuniões e discussões, optamos pelos critérios descritos na citação a seguir, que compõe a apresentação do livro.

No que concerne aos critérios utilizados para captação das imagens e dos históricos de vida, a escolha destas Mulheres de Axé se deu pela representatividade social das mesmas e pela construção familiar de empoderamento matriarcal dentro dos seus respectivos Terreiros de Candomblé e seus reflexos dentro do contexto baiano. Nesse sentido, aqui fizemos a escolha pautada em critérios de tradição e transmissão do Axé ao longo dos anos, no empreendedorismo desempenhado por essas mulheres e as suas respectivas comunidades, nas ações sociais desenvolvidas em prol das (os) mais necessitados (as), na integração social junto as comunidades do seu entorno e, finalmente, no empoderamento feminino esboçado na condução do Axé (CIRNE; SILVA, 2013, p. 48). 
Selecionadas as mulheres a serem entrevistadas, iniciamos a pesquisa direta. A cada encontro conhecíamos uma história de vida emocionante, e naquele momento tive oportunidade de entender a dor daquelas senhoras que relatavam suas histórias de vida, seus sofrimentos, toda discriminação, intolerância e racismo religioso que passaram. Percebia que muitas, em algum momento, misturavam-se com minha história de sofrimento, discriminação e racismo que vivenciei sem nem entender o que acontecia. Esse trabalho desenvolvido para a construção do livro Mulheres de Axé (Figura 13) foi decisivo para eu assumir definitivamente a minha condição de negro e reforçar a importância de me engajar, cada vez mais, na luta para impedir que outras crianças sofressem tudo que sofri na minha história de vida.

A partir do ano de 2014, minha vida teve uma radical mudança, pois se iniciava uma nova fase de luta e aprendizado sobre as questões raciais, fora da minha terra natal, Salvador, quando problemas financeiros fizeram com que eu fosse residir no interior da Bahia, na cidade de Vitória da Conquista. Esse município situa-se no Território de Identidade do Sudoeste da Bahia, um ambiente muito diferente da capital, começando pela temperatura muito fria, chegando, em alguns períodos do ano, a medir 7 graus. A princípio, as dificuldades foram muitas, pois, além da frieza do clima, as pessoas também eram frias, difíceis e muito preconceituosas, principalmente com os negros, que vivem, na sua maioria, distantes do centro, em bairros localizados na periferia ou na zona rural, e muitas dessas comunidades são originárias de remanescentes de quilombos. 


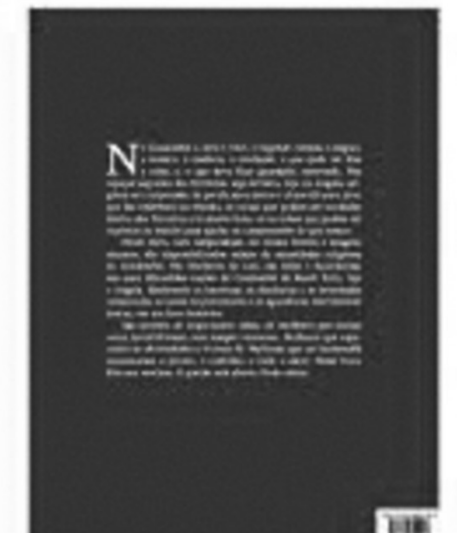

Fonte: Mulheres de Axé (REZENDE, 2013).

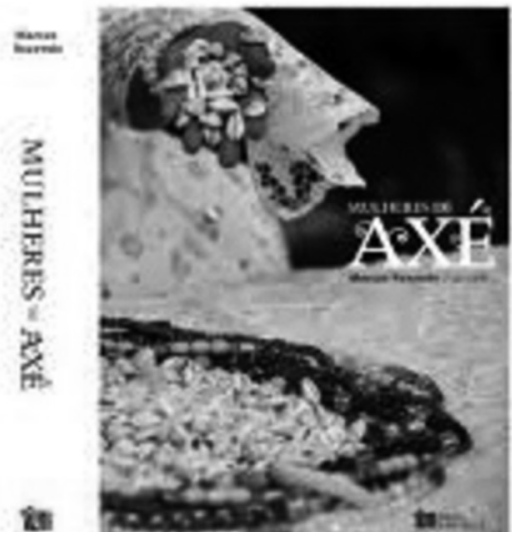

Figura 13

Imagem da capa do Livro Mulheres de Axé.

Para meu contentamento, logo que cheguei, tive a oportunidade de ser apresentado à senhora Elizabeth Ferreira Lopes, importante lideranças há mais de 25 anos, militante do movimento negro e defensora das comunidades quilombolas do município de Vitória da Conquista. Beta, como é conhecida por todos, imediatamente me levou ao encontro de outra importante liderança negra da cidade, o senhor Uelber Souza Barbosa, um jovem ativista das causas negras e da cultura afro-brasileira. Uelber e Beta faziam uma dupla que conduzia as ações dos Agentes Pastorais Negros(APNs) em todo o Sudoeste baiano. Sem demora, a 
dupla se transformou em um trio, e assim juntamos as ações de Beta e Uelber com as experiências e contatos com o movimento negro da capital e demos início a um trabalho que rendeu muitos frutos nos cinco anos que estivemos juntos.

A princípio, engajei-me nas duas ações que os APNs de Vitória da Conquista promoviam. A primeira, que já durava cerca de 20 anos, consiste no curso Pré-Vestibular Dom Climério, preparatório para jovens negros, quilombolas e pessoas de baixa renda. Essa ação tem uma importância fundamental na preparação desses jovens, principalmente após a criação das políticas públicas de inclusão, desenvolvidas pelos governos que chegaram ao poder no país a partir do ano de 2003, ou seja, a introdução, no Brasil, do sistema de cotas raciais, fomentando a esperança desses jovens de entrarem nas universidades, sendo o Dom Climério a única instituição que eles tinham para ajudá-los a conseguirem preparação eficiente e conquistarem uma vaga para o Ensino Superior.

Comecei trabalhando nesse projeto como professor voluntário de história do Brasil, mas logo fui me envolvendo com as questões administrativas e da coordenação pedagógica e, em pouco tempo, já era o principal parceiro de Beta e Uelber na construção das políticas públicas dos estudantes negros, secundaristas e universitários. Passamos a atuar junto com as universidades públicas da cidade, acompanhando o desempenho dos alunos e as políticas de permanência na universidade daqueles que tinham sido aprovados; lutamos ferrenhamente contra as fraudes das cotas, principalmente as dos estudantes quilombolas. 
A outra ação importante que os APNs desenvolvem há cerca de oito anos e que eu também passei a contribuir ativamente como colaborador e depois como membro do Conselho Fiscal e diretoria é a manutenção da Casa do Estudante Quilombola Zumbi dos Palmares, hoje Casa do Estudante Dandara dos Palmares, que surgiu a partir dos bons resultados que o Cursinho Dom Climério vinha conseguindo, ou seja, vários jovens quilombolas passavam no vestibular ou no ENEM.

Esses jovens muitas vezes não podiam permanecer na universidade por falta de condições financeiras satisfatórias e, principalmente, por não terem como morar na cidade. Nesse período, Beta e os companheiros do movimento negro da cidade resolveram montar uma casa para abrigá-los, sem custo de moradia, física e regimentalmente estruturada, e passou a receber os quilombolas universitários que começaram a ter toda estrutura para continuar os estudos. A Casa dispõe de dormitório coletivo para meninos e meninas, sala de estudo, refeitório, cozinha, área de lazer, internet e TV, além dos serviços de uma cozinheira e despesas de abastecimento de água e energia elétrica, por meio de fundos municipais e de pequena contribuição dos residentes, correspondendo, na época, à taxa de $\mathrm{R} \$$ 50,00 mensalmente.

A excelência do trabalho chegou a ser vencedora de edital do agosto da igualdade, Prêmio Manoel Faustino, promovido pela Secretaria Estadual de Promoção da Igualdade Racial da Bahia (SEPROMI) no ano de 2015, recebendo a importância de dez mil reais, revertida na melhoria das condições do espaço. A Casa contou, durante todo esse tempo (2008 a 2016), com o apoio incondicional da Prefeitura 
Municipal, que nunca mediu esforços para colaborar com o projeto, disponibilizando funcionários, fornecendo alimentação e transporte para atividades externas, quando solicitado. A figura 14, a seguir, ilustra a publicação sobre experiências da SEPROMI.

As ações promovidas por Beta e Uelber e por muitas outras lideranças do movimento negro de Vitória da

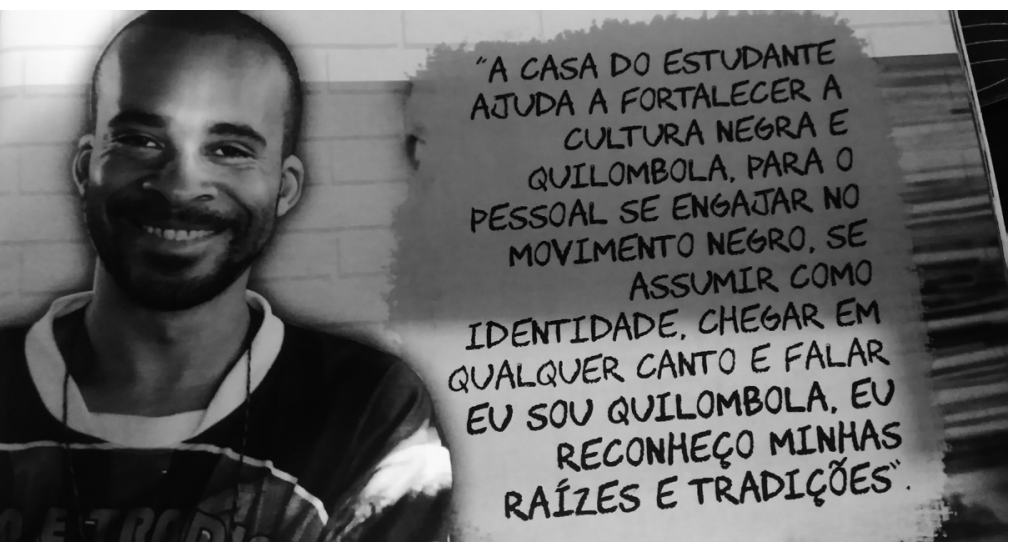

Figura 14

Catálogo sobre experiências, SEPROMI, Governo do Estado da Bahia. 
Conquista já haviam conquistado espaço no governo municipal quando eu cheguei ao município. Já existia, por exemplo, vinculado à Secretaria Municipal de Desenvolvimento Social (SEMDES), um Núcleo de Promoção da Igualdade Racial, porém sem orçamento próprio e dependente da boa vontade do secretário para desenvolver suas atividades; então, começamos a trabalhar para a construção de um organismo autônomo.

No começo não foi fácil, pois a maioria dos secretários de governo questionava o porquê de um órgão independente ao considerarem que já existia o Núcleo da Igualdade Racial. Podemos observar que o racismo vinha da própria instituição, sob o argumento da falta de orçamento e da dificuldade em fazer uma reforma administrativa, ou seja, tudo era motivo para não aprovar nosso pleito. Não desistimos e começamos outra estratégia, que consistiu no início de uma série de atividades e mobilizações de vários segmentos negros da cidade para mostrar ao prefeito que já existia uma organização social negra, o que justificava um órgão público que lhe representasse.

Realizamos rodas de conversas, rodas de capoeira em praça pública, seminários sobre religiões de matriz africana, encontros com as comunidades quilombolas, conferências de Promoção de Igualdade Racial, reuniões para elaboração do Plano de Igualdade Racial municipal, encontro de mulheres negras, feira de arte indígena, viagens culturais e carnavalescas para Salvador, com mulheres de Terreiro de Vitória da Conquista que participavam de vários eventos culturais e religiosos e desfilavam no carnaval de Salvador, no Afoxé Filhas de Gandhi, além da realização da Alvorada 
dos Ojás, evento organizado pelo Coletivo de Entidades Negras, no mês de novembro, em Salvador.

A atividade religiosa de amarrar os Ojás nas árvores passou a ser realizada também em Vitória da Conquista, com uma grande cobertura de vários veículos de comunicação, chamando a atenção de boa parte da população e também das autoridades municipais. Com toda essa mobilização, o prefeito foi sendo sensibilizado e acabou entendendo a necessidade da criação do tão desejado órgão de Promoção da Igualdade Racial da cidade. Assim, no ano de 2014, após reforma administrativa, o Núcleo de Promoção da Igualdade Racial se desvinculou da SEMDES e se transformou em uma Coordenação, com status de Secretaria de Igualdade Racial, ligada diretamente ao gabinete do prefeito, com dotação orçamentária e a autonomia necessária para organizar as políticas públicas raciais do município.

Após consulta do prefeito a algumas lideranças negras do município, meu nome foi indicado para ocupar o cargo de gerente de comunidade e povos tradicionais na Coordenação da Igualdade Racial. Nesse momento, tive oportunidade de aprofundar e estreitar ainda mais os laços com os Povos de Terreiros e as comunidades quilombolas, o que foi importante para compreender melhor a realidade desses segmentos sociais e a minha condição de ser negro.

Durante os dois anos à frente da gerência da Coordenação, tive oportunidade de conhecer de perto o cotidiano de algumas comunidades quilombolas e desenvolver atividades de formação política, organização comunitária, mutirões para construção de ações de sustentabilidade, encontros de mulheres quilombolas e intermediações de projetos de 
construções de casas do Programa Nacional de Habitação Rural - PNHR.

Em relação às comunidades de terreiros, a minha passagem pela Coordenação foi muito importante para entender ainda mais a necessidade de construir um trabaIho que permitisse o combate ao racismo religioso. Uma das principais atividades que tive oportunidade de coordenar nesse período foi o cadastramento de 45 casas de religião de matriz africana do território, entre terreiros de Candomblé de várias nações (Ketu, Jejê, Angola) e centros de umbanda. Nessas casas, tive oportunidade de conversar com várias crianças e adolescentes que relataram inúmeros casos de racismo religioso nas escolas.

Em dezembro de 2016, finalizava minha atividade como membro do governo municipal e, no ano seguinte, retomei com mais afinco as ações no movimento social, dedicando-me à organização de uma Coordenação Municipal do Coletivo de Entidades Negras e às ações do Centro de Educação Arte e Movimento (CETA), especialmente à escola de capoeira dirigida por Lázaro Vieira - ou Mestre Dendê (Figura 15), que desenvolvia um excelente trabalho com jovens da periferia da cidade, reintegrando muitos desses negros ao convívio social. Também contribuí com a formação do Coletivo Caminho dos Búzios, que consiste em uma rede de religiosos de matriz africana, fundado com a finalidade de construir uma organização legal de apoio aos terreiros de Candomblé e casas de umbanda da cidade. A Figura 15 mostra um grupo de jovens e de crianças na sede do grupo Arte e Movimento no dia de formatura e batizado dos alunos de capoeira. 
Com a saída da prefeitura, retornei, com maior carga horária, para minhas atividades em sala de aula. Era preciso atualizar as leituras, a preparação dos planos de aulas, os estudos sobre os novos conteúdos do Ensino Fundamental e Médio e as provas do ENEM. Assim, comecei a estudar e repensar a ideia de retomar a vida acadêmica, que tinha ficado para trás há algum tempo, devido a todas as atividades que optei por desenvolver na vida.

No início do mês de janeiro de 2017, já decidido a encontrar algum estudo voltado para as questões étnico-raciais na
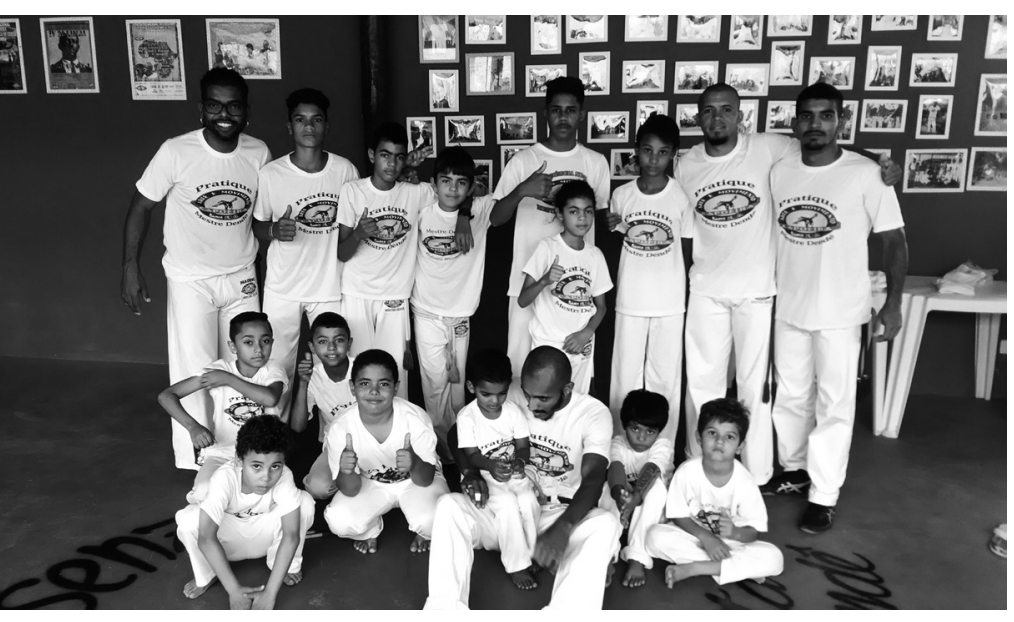

Figura 15

Fonte: Dados do pesquisador.

Grupo da escola

de capoeira Mestre

Dendê. 
universidade, encontrei a notícia que a UFSB tinha recebido aprovação da Coordenação de Aperfeiçoamento de Pessoal de Nível Superior (CAPES) para a realização da primeira turma do Programa de Pós-Graduação em Ensino e Relações Étnico-Raciais (PPGER). A partir dessa notícia, passei a acompanhar o site da universidade para saber o início do processo seletivo. Foram praticamente seis meses acompanhando e estudando o que podia sobre a temática racial e, enfim, no mês de julho, o edital foi publicado, dando início ao processo seletivo no mês seguinte.

Foram ofertadas cerca de 30 vagas e, para conseguir voltar à universidade, seria preciso vencer três etapas: aceitação do projeto, aprovação na prova escrita e na entrevista. Depois de tanta convivência nos terreiros e conversas com as crianças e jovens das casas, já sabia qual a temática que pretendia trabalhar: o racismo religioso que esses grupos sofriam na escola. Meu projeto foi aceito e, em agosto, recebi o resultado final das três etapas: fui aprovado. E um mês depois lá estava eu de volta à universidade, agora, para elaborar um trabalho que me conferisse o título de mestre.

A experiência adquirida durante o período de cumprimento dos créditos dos componentes curriculares foi algo completamente inovador. Os novos conceitos e autores apresentados pela equipe de professores me transformaram, principalmente ao levar em conta que já estava há tanto tempo distante da realidade acadêmica, envolvido profissionalmente com as questões da educação básica.

O primeiro momento foi difícil, pois precisava reelaborar os conhecimentos construídos até então, em função das novas informações e leituras propostas pelos docentes. 
Mesmo já tendo algum conhecimento de aspectos teóricos do movimento negro, conhecendo um pouco da sua história, como já relatei no texto anteriormente, as contribuições apresentadas pela professora Célia Regina da Silva, principalmente no que se refere às políticas públicas para as Relações Étnico-Raciais, abriram caminhos importantes para transformar as bases do projeto de intervenção de conclusão do curso.

Os autores estudados nesse componente curricular apresentavam conceitos e experiências práticas relativas à elaboração de políticas públicas para Educação das Relações Étnico-Raciais, como Nilma Lino Gomes, Vera Maria Candau, Kabengele Munanga, Maicelma Maia Souza, que ampliaram muito a minha visão sobre racismo, discriminação, intolerância e práticas pedagógicas inclusivas dessas minorias raciais.

\begin{abstract}
A educação reivindicada pelo movimento negro no Brasil, argumenta Nilma Lino Gomes, atravessa uma situação de tensão dupla entre configurar-se, de fato, como direito social para todos, e reconhecer e respeitar as diferenças. Ao assumir essa dupla função, acrescenta Gomes, a escola brasileira desde a educação básica até o ensino superior é responsável para construir práticas, projetos e iniciativas eficazes de combate ao racismo e de superação das desigualdades Raciais. (Gomes, op. cit. p. 102). Na perspectiva de Paulo Freyre, somos desafiados a construir uma Pedagogia do oprimido. No entanto, a questão racial nos ajuda a racializar ainda mais essa proposta. Somos levados a construir uma Pedagogia de Diversidade (GOMES, 2017, p. 102).
\end{abstract}

Novas informações apresentadas, como essa citada acima da professora Gomes, trouxeram importantes contribuições para o aperfeiçoamento do projeto inicial de 
trabalho, o que permitiu a reconstrução de ideias e pensamentos na estruturação de uma educação de base diversificada, multicultural e que contribuísse para a respeitabilidade e fim do racismo religioso, particularmente praticado contra crianças e jovens religiosos de matriz africana na escola.

O componente curricular proposto pela professora Francismary Alves Silva, ainda no primeiro quadrimestre, também foi de fundamental importância para o repensar das propostas iniciais do projeto. A princípio, o componente curricular "Imperialismos e descolonizações" parecia ser apenas uma disciplina que falaria de forma factual sobre as questões relativas ao processo de colonização europeia na África e na América, durante o período da Idade Moderna, entre os séculos XV e XVIII, e do fenômeno do imperialismo e do neocolonialismo no século XIX. No entanto, foi muito mais que isso. A sua formação de historiadora conseguiu trazer para mim uma visão muito contextualizada de todos os processos dominadores dos europeus sobre o novo mundo, de forma a relacionar o antigo sistema colonial com a colonização moderna. Além disso, ela introduziu os conceitos da decolonização; a ideia de que a expulsão material dos colonizadores determinava o fim da subalternidade e dependência dos colonizados foi substituída pela noção de que mesmo sem a presença física dos europeus, seus pensamentos e ações continuavam dominando a África e a América.

O texto feito nesse componente curricular foi muito importante e, por ter acontecido no primeiro quadrimestre, contribuiu de forma decisiva para preparar os estudos que iria fazer no, seguinte, com o professor Rafael Siqueira Guimarães, que introduziu muitos autores e conceitos teóricos 
novos para mim. Foi nesse momento que tive a oportunidade de conhecer o pensamento de Spivak (2010), que nos provocou a entender os aspectos teóricos e práticos da subalternidade, que corresponde à compreensão da submissão dos povos colonizados, e à importância de poder falar e rediscutir a dominação a partir do seu próprio lugar.

Os postulados de Grosfoguel (2016) me apresentaram o conceito de decolonialidade e perspectivas negras a partir das características de um projeto decolonial, bem como a produção do conhecimento e as narrativas a partir do "loci geopolíticos e corpos-políticos de enunciação" (GROSFOGUEL, 2016). Ele chama a atenção para o conhecimento a partir de uma perspectiva negra das Américas e do Caribe, além de conciliar os estudos com Anzaldúa (2000), que nos mostra a importância de agir coletivamente na tentativa de reconstruir a dignidade do sujeito dominado, para não ficar apenas reagindo à dominação, mas indo ao encontro e juntos agir contra o dominador.

Contudo, não é suficiente se posicionar na margem oposta do rio, gritando perguntas, desafiando convenções patriarcais, brancas. Um ponto de vista contrário nos prende em um duelo entre opressor e oprimido; fechados/as em um combate mortal, como polícia e bandido, ambos são reduzidos a um denominador comum de violência. O "contraposicionamento" refuta os pontos de vista e as crenças da cultura dominante por isso, é orgulhosamente desafiador. Toda reação é limitada por, e subordinada à, aquilo contra o qual se está reagindo. Porque o "contraposicionamento" brota de um problema com autoridade - tanto externa como interna representa um passo em direção à liberação da dominação cultural. Entretanto, não é um meio de vida. A uma determinada altura, no nosso caminho rumo a uma nova consciência, teremos que deixar a margem oposta, com o corte entre os dois combatentes mortais 
cicatrizado de alguma forma, a fim de que estejamos nas duas margens ao mesmo tempo e, ao mesmo tempo, enxergar tudo com olhos de serpente e de águia. Ou talvez decidamos nos desvencilhar da cultura dominante, apagá-la por completo, como uma causa perdida, e cruzar a fronteira em direção a um território novo e separado. Ou podemos trilhar uma outra rota. As possibilidades são inúmeras, uma vez tenhamos decidido agir, em vez de apenas reagir (ANZALDÚA, 2000, p. 2).

Além disso, o componente foi muito importante para o aprofundamento sobre o tema de minha pesquisa, pois, como dito, trouxe informações sobre subalternidade, decoIonização e submissão dentro de uma perspectiva racial e de gênero, introduzindo, desse modo, o repensar de algumas práticas na construção do meu projeto de intervenção.

O conteúdo estudado com a professora Ana Cristina Peixoto, relacionado ao componente curricular voltado para as práticas pedagógicas para educação étnico-racial nas escolas, acrescentou conhecimento satisfatório para que eu pudesse entender como construir ações possíveis para aplicação da legislação, principalmente da Lei n. 10.639 (BRASIL,2003) nos espaços escolares. Esses estudos mostraram a importância da formação do professor, do gestor e de todos os envolvidos no processo de ensino-aprendizagem em relação à educação étnico-racial.

Finalizando essa primeira etapa dos estudos, tive o grande prazer de aprender com a professora Cynthia de Cassia Santos Barra a importância do livro como potência transformadora da humanidade, além de conhecer com detalhes a história do livro. Discutimos por meio da obra de Foucault a ideia dos dispositivos, que consiste em ser 
um conceito multilinear, que combina estrategicamente campos de saber, relações de poder e modos de subjetivação, e conhecemos formas de livros novos, como o livro de comunidade apresentado em um dos nossos seminários de qualificação, realizado com a presença do professor peruano Elias de La Cruz. Foi a partir desse componente curricular que repensei a forma que construiria o produto final do mestrado, passando a concebê-lo como livro em forma de cartilha.

Essa caminhada até este momento permitiu mais do que esses novos conhecimentos adquiridos por meio dos professores nas salas de aula, pois, durante todo esse tempo, participamos de cinco seminários de qualificação das nossas pesquisas, com a participação de professores doutores de várias universidades latino-americanas, e de outros estados do Brasil, que contribuíram decisivamente na nossa formação e aperfeiçoamento do trabalho final.

Além dos conhecimentos adquiridos com os componentes curriculares do mestrado, e das leituras complementares, tivemos textos produzidos e aceitos para serem publicados em livros e revistas, que debatem temáticas referentes à decolonização, A educação multiculturalista, ao racismo religioso, bem como acerca da contribuição do movimento negro na construção das políticas públicas para aplicação da Lei n. 10.639 e a consequente diminuição do racismo religioso nos ambientes educacionais.

Outra maneira de aprimoramento e aprofundamento do conhecimento proporcionado pelo programa de pós-graduação foi a possibilidade de participar em alguns eventos de cunho acadêmico científico, que possibilitaram a troca 
de experiências com outros estudiosos de temáticas semeIhantes, além do enriquecimento do aprendizado.

Durante esse período, apresentei, entre outros: comunicação oral na Semana do Pertence de 2017, do Programa de Relações Étnico-raciais da Universidade Estadual do Sudoeste da Bahia - UESB (ODEERE); comunicação oral em grupo de trabalho do Fórum Social Mundial em 2017, em Salvador; mesa redonda na Faculdade Santo Agostinho, em Vitória da Conquista, na Jornada de Direitos Humanos da Faculdade de Direito; cursos e palestras em escolas de Ensino Médio da rede pública e privada, durante quase todo o mês de novembro de 2017, com a temática da lgualdade Racial; palestra sobre racismo religioso nas escolas, durante o Encontro Internacional de Educação na Universidade Estadual de Santa Cruz (UESC), em junho de 2018; mesa redonda também na UESC, dessa vez juntamente com a professora Ana Cristina Peixoto, minha orientadora, no $1^{\circ}$ Simpósio de Literatura Africana e Afro-brasileira; comunicação oral no Simpósio de Iniciação Científica, no dia 28 de novembro de 2019, na Faculdade Santo Agostinho, em Vitória da Conquista; e palestra com a temática Religiões de Matriz Africana e Racismo Religioso, na Faculdade de Tecnologia Científica (FTC), também em Vitória da Conquista, no dia 30 de novembro de 2019.

Finalizando essa análise, consegui perceber todo o processo que passei para me reconhecer como um homem negro e avalio que foi muito importante toda essa "viagem interior" e todo o aprendizado recente. Agora percebo que introjetei a ideia da luta pela igualdade racial e passei a viver cotidianamente enfrentando desafios para promover uma 
educação cada vez mais inclusiva, multiculturalista, que discuta as questões raciais, culturais, sociais, humanas, econômicas, de forma inter-relacionada, com o objetivo de contribuir para promover o respeito, a diversidade e alteridade.

Nem mesmo esteticamente eu consigo mais me apresentar como me apresentei durante quase 50 anos da minha vida, de uma forma muito mais próxima do

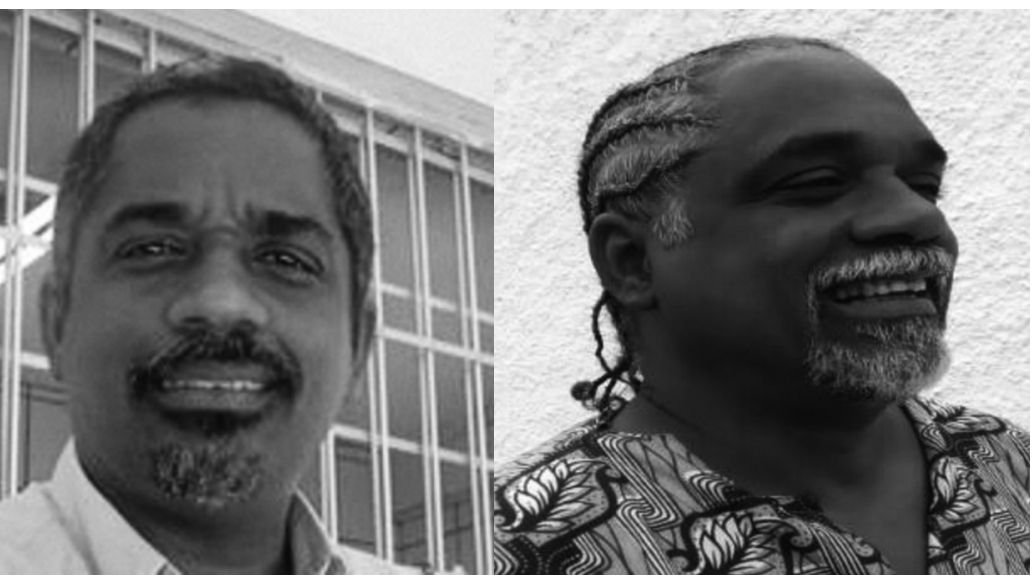

Figuras 16 e 17

Fotografias do autor, 2005 e 2018. 
embranquecimento do que na minha negritude, como podemos perceber nas imagens ao lado (Figuras 16 e 17).

Como pôde ser observado pelos relatos e análises aqui apresentados, a minha história de vida profissional e cidadã está intrinsecamente relacionada com a problemática que apresento nesta obra.

Entendo a importância de toda esta produção como fundamental para uma continuidade destes estudos e destas ações sociais de combate ao racismo religioso daqui para frente, de forma mais cotidiana e permanente na minha existência, esperando que esta obra possa contribuir e instigar outras pesquisas nesta temática.

A seguir, será apresentada a pesquisa direta realizada, abrangendo a descrição dos conceitos metodológicos que a embasaram e os resultados obtidos por meio das técnicas e fontes utilizadas. 